\title{
Article \\ Human Epidermal Zinc Concentrations after Topical Application of ZnO Nanoparticles in Sunscreens
}

\author{
Zahra Khabir ${ }^{1,2,+}{ }^{\circ}$, Amy M. Holmes ${ }^{3,+}$, Yi-Jen Lai ${ }^{1}$, Liuen Liang ${ }^{1,2}$, Anand Deva ${ }^{1}$, Michael A. Polikarpov ${ }^{4}$, \\ Michael S. Roberts $3,5, * \mathbb{D}$ and Andrei V. Zvyagin 1,6,*(D) \\ 1 Department of Physics and Astronomy \& Earth and Planetary Sciences \& Clinical Medicine, \\ Macquarie University, Sydney 2109, Australia; zahra.khabir@mq.edu.au (Z.K.); yi-jen.lai@mq.edu.au (Y.-J.L.); \\ liuen.liang@mq.edu.au (L.L.); anand.deva@mq.edu.au (A.D.) \\ 2 ARC Centre of Excellence for Nanoscale BioPhotonics, Sydney 2109, Australia \\ 3 Clinical Health Sciences and Basil Hetzel Institute for Translational Health Research, \\ University of South Australia, Adelaide 5000, Australia; amy.holmes@unisa.edu.au \\ 4 National Research Centre "Kurchatov Institute", Moscow 123098, Russia; polikarpov.imp@gmail.com \\ 5 Diamantina Institute, University of Queensland, Brisbane 4072, Australia \\ 6 Centre of Biomedical Engineering, Sechenov University, Moscow 119991, Russia \\ * Correspondence: m.roberts@uq.edu.au (M.S.R.); andrei.zvyagin@mq.edu.au (A.V.Z.) \\ + These authors contributed equally to this work.
}

\section{check for}

updates

Citation: Khabir, Z.; Holmes, A.M.; Lai, Y.-J.; Liang, L.; Deva, A.; Polikarpov, M.A.; Roberts, M.S.; Zvyagin, A.V. Human Epidermal Zinc Concentrations after Topical Application of $\mathrm{ZnO}$ Nanoparticles in Sunscreens. Int. J. Mol. Sci. 2021, 22, 12372. https://doi.org/10.3390/ ijms222212372

Academic Editors: Bice Conti and Ida Genta

Received: 24 October 2021

Accepted: 11 November 2021

Published: 16 November 2021

Publisher's Note: MDPI stays neutral with regard to jurisdictional claims in published maps and institutional affiliations.

Copyright: (c) 2021 by the authors. Licensee MDPI, Basel, Switzerland. This article is an open access article distributed under the terms and conditions of the Creative Commons Attribution (CC BY) license (https:// creativecommons.org/licenses/by/ $4.0 /)$.

\begin{abstract}
Zinc oxide nanoparticle (ZnO NP)-based sunscreens are generally considered safe because the $\mathrm{ZnO}$ NPs do not penetrate through the outermost layer of the skin, the stratum corneum (SC). However, cytotoxicity of zinc ions in the viable epidermis (VE) after dissolution from ZnO NP and penetration into the VE is ill-defined. We therefore quantified the relative concentrations of endogenous and exogenous $\mathrm{Zn}$ using a rare stable zinc-67 isotope $\left({ }^{67} \mathrm{Zn}\right) \mathrm{ZnO}$ NP sunscreen applied to excised human skin and the cytotoxicity of human keratinocytes (HaCaT) using multiphoton microscopy, zinc-selective fluorescent sensing, and a laser-ablation inductively coupled plasma-mass spectrometry (LA-ICP-MS) methodology. Multiphoton microscopy with second harmonic generation imaging showed that ${ }^{67} \mathrm{ZnO}$ NPs were retained on the surface or within the superficial layers of the SC. Zn fluorescence sensing revealed higher levels of labile and intracellular zinc in both the SC and VE relative to untreated skin, confirming that dissolved zinc species permeated across the SC into the VE as ionic Zn and significantly not as ZnO NPs. Importantly, the LA-ICP-MS estimated exogenous ${ }^{67} \mathrm{Zn}$ concentrations in the $\mathrm{VE}$ of $1.0 \pm 0.3 \mu \mathrm{g} / \mathrm{mL}$ are much lower than that estimated for endogenous VE zinc of $4.3 \pm 0.7 \mu \mathrm{g} / \mathrm{mL}$. Furthermore, their combined total zinc concentrations in the VE are much lower than the exogenous zinc concentration of 21 to $31 \mu \mathrm{g} / \mathrm{mL}$ causing VE cytotoxicity, as defined by the half-maximal inhibitory concentration of exogenous ${ }^{67} \mathrm{Zn}$ found in human keratinocytes (HaCaT). This speaks strongly for the safety of $\mathrm{ZnO}$ NP sunscreens applied to intact human skin and the associated recent US FDA guidance.
\end{abstract}

Keywords: nanotoxicology; $\mathrm{ZnO}$ nanoparticles; isotope tracing; epidermal zinc; multiphoton microscopy

\section{Introduction}

Advances in the rapidly growing field of nanotechnology have generated several new and effective products now being used in cosmetic formulations [1-3], in dermatology [4,5], and in nanomedicine [6-8]. However, due to the widespread application of nanotechnology products in industry, medicine and daily life, concerns have been raised as to whether they lead to adverse effects to humans and environment [9-11], including previously unknown toxicities [12]. This aspect has led to the field of nanotoxicology, defined as a toxicological assessment of engineered nanomaterials [13].

Zinc oxide (ZnO) nanoparticles (NPs) are widely used in cosmetic products, with 70\% of all $\mathrm{ZnO}$ NPs now being used in personal care products, including as sunscreens to filter 
the harmful ultraviolet sunlight radiation (UVA (320-400 nm) and UVB (290-320 nm)) [14]. $\mathrm{NPs}$ of $\mathrm{ZnO}(<30 \mathrm{~nm})$ are typically incorporated into sunscreen formulations as they are aesthetically appealing, appearing transparent on the skin, and are effective in reflecting UV absorption [15]. Typically, ZnO NPs with a diameter between 20 and $100 \mathrm{~nm}$ are incorporated into sunscreen formulations [16], which is the size range selected for the stable isotope engineered $\mathrm{ZnO}$ NPs designed and used in this study.

Controversy has existed over the last decade regarding the safety of ZnO NPs [17], with concerns raised regarding in vitro studies used to study ZnO NP cytotoxicity [18]. ZnO NPs are suggested to induce cyto- and genotoxicity in human epidermal keratinocytes through DNA damage, intracellular reactive oxygen species (ROS), and oxidative stress [19,20]. However, the cytotoxic concentrations of ZnO NPs vary with the type of immortalised keratinised monolayers and cell culture media used and range from 0.8 to $5 \mu \mathrm{g} / \mathrm{mL}$ in the human epidermal cell line (A431) [21] to $30-50 \mu \mathrm{g} / \mathrm{mL}$ for the HaCaT cell line in DMEM [22]. Typically, $\mathrm{ZnCl}_{2}$ or $\mathrm{ZnSO}_{4}$ have been used to model soluble $\mathrm{Zn}$ salts at equal stoichiometric $\mathrm{Zn}^{2+}$ concentrations as a positive control $[23,24]$. Unfortunately, these studies do not translate to in vivo human skin toxicity as the cytotoxic concentrations are less than or similar to the reported endogenous human epidermal zinc concentrations of $60 \mu \mathrm{g} / \mathrm{g}$ of dry weight $[25,26]$. Thus, it is apparent that in vitro keratinocyte monolayers may lead to misleading conclusions not relevant to in-use scenarios and the use of in vivo or ex vivo human skin is required to define the realistic safety of $\mathrm{ZnO} N P s$ and their dissolved zinc species.

To date, research related to $\mathrm{ZnO}$ NPs applied to human skin has been focussed on the extent to which ZnO NPs penetrate human skin after topical application. Gamer et al. [27] and Cross et al. [28] analysed the penetration of ZnO NPs across full-thickness porcine skin and human epidermal membranes, respectively. Zvyagin et al. [29] and Roberts et al. [30] were the first to use non-invasive multiphoton imaging to show that zinc oxide does not penetrate the outermost layer of the skin, the stratum corneum (SC), a finding also reported in later studies [31-35]. According to a published report by the Therapeutic Goods Administration (TGA) of Australia concerning the safety of inorganic sunscreens, $\mathrm{ZnO}$ NPs do not cause adverse health effects unless they reach the viable epidermis (VE) [36]. Since their penetration is limited to the SC, systemic absorption and consequent toxicity is unlikely $[16,20,28]$.

The dissolution of ZnO NPs at the sunscreen-skin interface and subsequent permeation of solubilised zinc species throughout the VE has been observed [31]. It has been known for several decades that the human skin has an acid mantle with a pH 4-6 and a $\mathrm{pH}$ gradient across the $\mathrm{SC}$ ranging from $\mathrm{pH} 4.5-5.3$ at the surface to $\mathrm{pH} 6.8$ in the stratum basale [37]. This can elicit the dissolution of topically applied ZnO NPs and concomitant percutaneous absorption of zinc. Previously, an increase of zinc concentration in human skin has been reported following the exposure to topical formulations containing $\mathrm{ZnO}[38,39]$, although conversely, in pig skin after application of microfine $\mathrm{ZnO}$, one study suggested that the levels found were similar to those dosed with the control vehicle [27]. Our work using in vitro human epidermal cells, viable and non-viable ex vivo human skin showed that solubilised zinc species that underwent dissolution can penetrate human skin after topical application of $\mathrm{ZnO}$ NPs used in commercial sunscreens even after simulated in use scenario $[31,40,41]$. To the best of our knowledge, our work showing an increase in epidermal zinc concentrations after application of ZnO NPs are the only in vivo human studies to date [42-44].

As zinc is the second-most abundant trace element in the human body [45], Gulson et al. [46] used the traceable isotope ${ }^{68} \mathrm{Zn}$ to quantify zinc by inductively coupled-plasmamass spectrometry (ICP-MS) in blood and urine samples of volunteers exposed to sunscreens containing ZnO NPs in an outdoor setting. They also measured zinc absorption in indoor studies using photochemical-based formulations containing ZnO NPs (mean diameter, $\sim 30 \mathrm{~nm} ;{ }^{68} \mathrm{Zn}$ enrichment, 52\%) [47]. They found a small increase of ${ }^{68} \mathrm{Zn}$ within volunteers' blood and urine after a 5-day application, with the highest levels being observed 
for women dosed with $\mathrm{ZnO}$ NPs. As ICP-MS only measures $\mathrm{Zn}$ ions after acid digestion of samples, Gulson et al. were unable to determine whether intact $\mathrm{ZnO}$ or solubilised zinc species penetrated the skin and the localised skin concentrations were not determined.

In this work, we applied Gulson's approach [48] to definitively quantify zinc ion absorption from $\mathrm{ZnO}$ NPs into the VE to determine the resulting exogenous zinc concentrations achieved after topical application to intact human skin, as well as to relate them to the endogenous zinc concentrations and to define the exogenous zinc concentrations associated with zinc-induced human keratinocyte (HaCaT cell line) cytotoxicity. We synthesised $\mathrm{ZnO}$ NPs enriched with ${ }^{67} \mathrm{Zn}$ and investigated the distribution of ${ }^{67} \mathrm{ZnO}$ NPs and dissolution products in either excised human skin epidermis (HSE) or freshly excised full-thickness human skin topically treated with ${ }^{67} \mathrm{ZnO} \mathrm{NP}$ sunscreen formulation. The distribution of ${ }^{67} \mathrm{ZnO}$ nanocrystals on the superficial layers of HSE was imaged by using two-photon second harmonic generation (SHG) microscopy characterised by the reduced background $[29,49,50]$. The distribution of free ${ }^{67} \mathrm{Zn}^{2+}$ and ${ }^{67} \mathrm{Zn}$ labile species in SC and VE of stained HSE with zinquin and Zinpyr-1 (ZP1), respectively, were acquired by confocal microscopy. ${ }^{67} \mathrm{Zn}$ amounts in freshly excised full-thickness human skin were quantified and mapped by ICP-MS and LA-ICP-MS, respectively. Percutaneously absorbed ${ }^{67} \mathrm{Zn}$ in VE was compared with IC50 assayed in human keratinocytes (HaCaT cells). Figure 1 illustrates the multi-modal techniques used in this study.

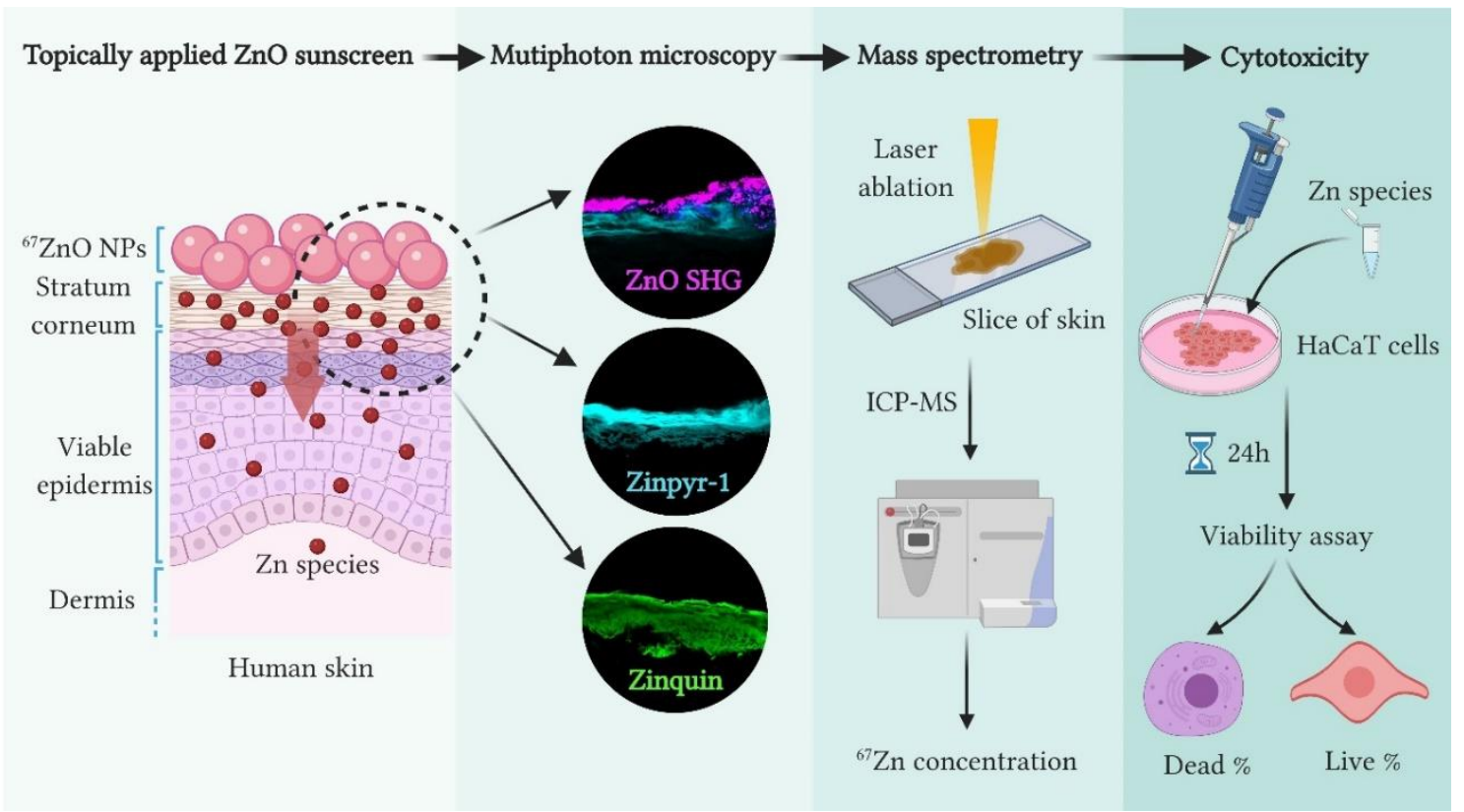

Figure 1. Schematic illustration of techniques used in this study to image and quantify the permeated zinc species formed by ${ }^{67} \mathrm{ZnO}$ dissolution on the skin surface. Zinc species were detected by multiphoton microscopy using the second harmonic generation signal of $\mathrm{ZnO}$ nanocrystals, by multiphoton and confocal fluorescence microscopies using fluorescent zinc sensors, Zinquin ethyl ester and Zinpyr-1; and mass spectrometry. Created with BioRender.com.

This is the first time, to the best of our knowledge, that the potential human epidermal cytotoxicity of sunscreens that incorporate ZnO NPs has been evaluated based on the exogenous zinc ion concentrations detected in the epidermis. Our results support the view that sunscreens containing $\mathrm{ZnO}$ NPs are safe after topical application to intact human skin.

\section{Results and Discussion}

\subsection{Characterisation of ${ }^{67} \mathrm{ZnO}-\mathrm{PEG} N \mathrm{NS}$}

Transmission electron microscopy (TEM) images of micrometre-scale and nanometrescale ${ }^{67} \mathrm{ZnO}$ powders are presented in Figure $2 \mathrm{a}, \mathrm{b}$. The as-synthesised ${ }^{67} \mathrm{ZnO}$-PEG NPs were spheroidal in shape with a mean size of $20 \mathrm{~nm}$. The particle size distribution was 
analysed using TEM images by fitting the histogram with a normal distribution function (Figure 2c,d), yielding FWHM (full width at half maximum), of $4 \mathrm{~nm}$. By controlling the synthesis parameters, as-synthesised NPs were in the diameter range of 20-100 nm (see Supplementary Materials, Section S1, Figures S1 and S2 and Table S1). The acquired and analysed XRD spectra of the micrometre-scale and nanometre-scale ${ }^{67} \mathrm{ZnO}$ powders (Figure 2e) showed hexagonal wurtzite crystal structure for both samples, reference code 01-079-207 of the International Centre for Diffraction Data (ICDD). ${ }^{67} \mathrm{ZnO}$-PEG NP XRD peaks were broadened in comparison with micrometre-scale ${ }^{67} \mathrm{ZnO}$. These results show the potential of the reported co-precipitation protocol to produce near monodispersed $\mathrm{ZnO}$ NPs with a tuneable size range.

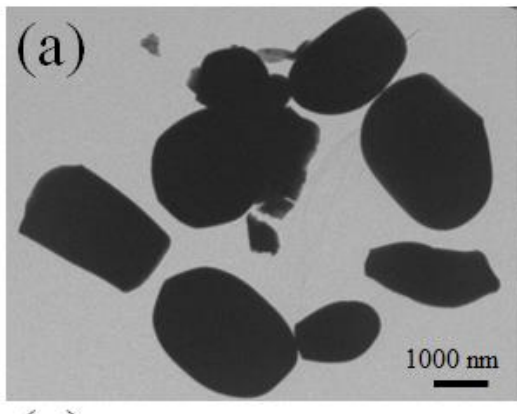

(c)
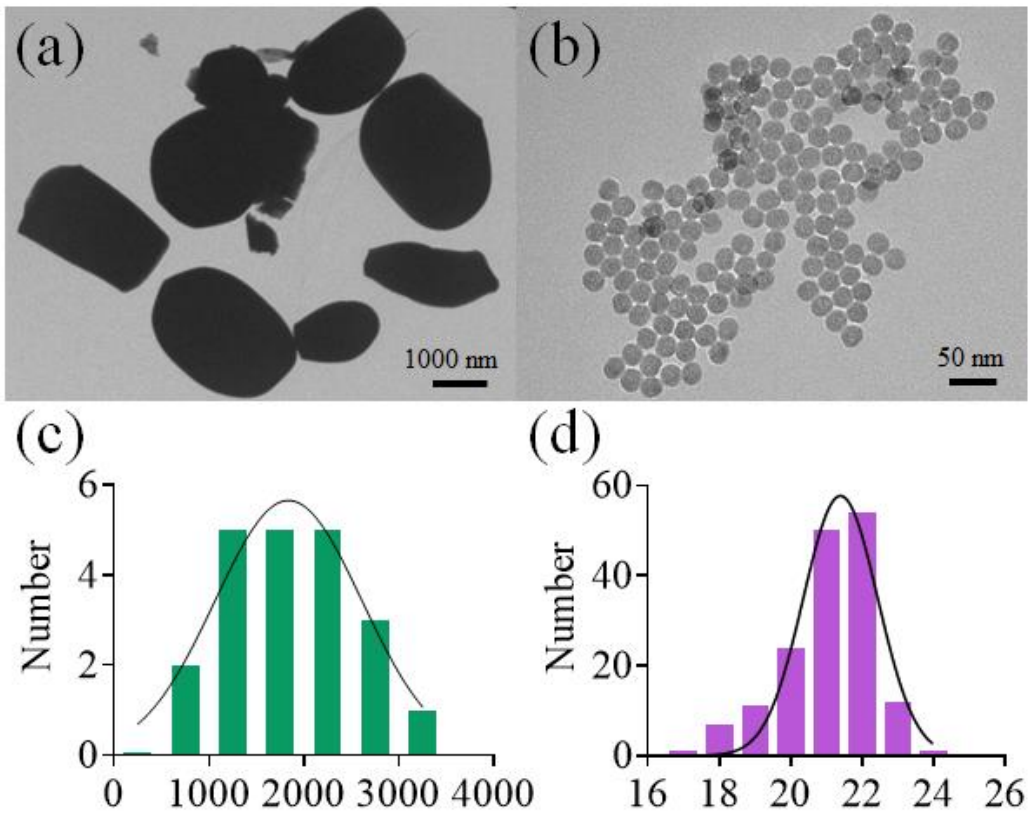

(d)
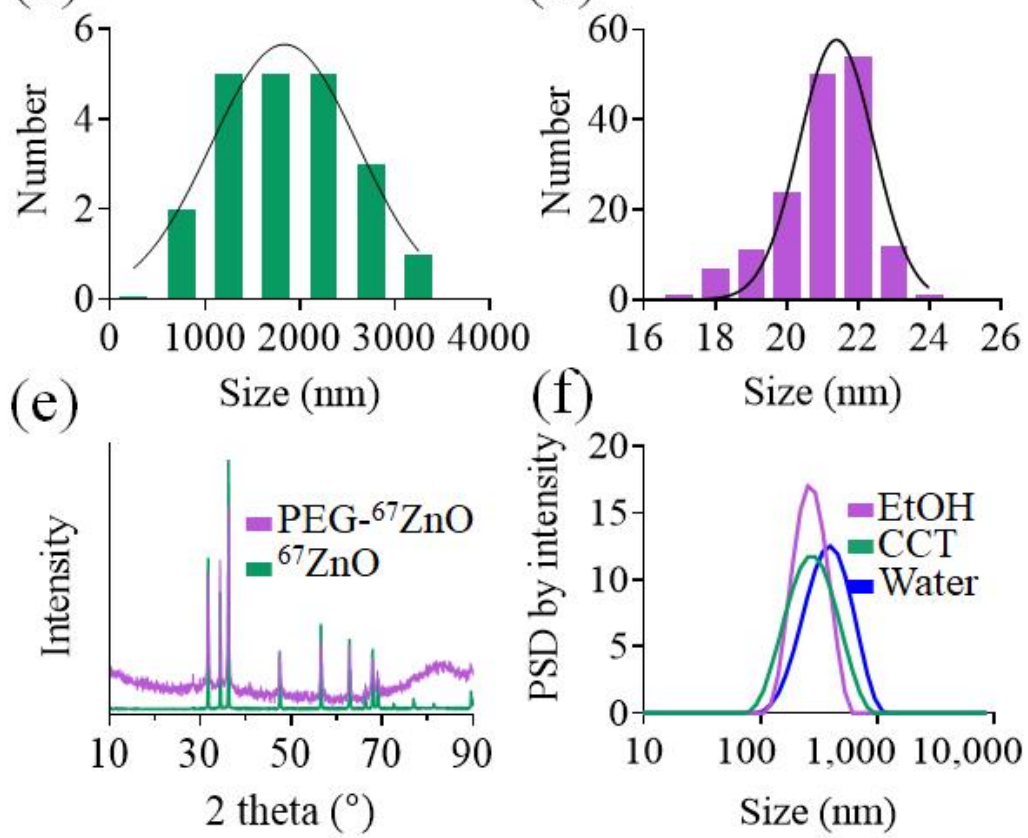

Figure 2. (a) TEM image of as-received micron-sized ${ }^{67} \mathrm{ZnO}$ powder. Scale bar, $2 \mu \mathrm{m}$. (b) TEM image of ${ }^{67} \mathrm{ZnO}$-PEG NPs synthesised by the co-precipitation method. Scale bar, $50 \mathrm{~nm}$. Particle size distribution histograms of (c) micron-sized ${ }^{67} \mathrm{ZnO}$ and (d) ${ }^{67} \mathrm{ZnO}-\mathrm{PEG}$ NPs powders. Solid curves show Gaussian fitting. (e) XRD patterns of micro- ${ }^{67} \mathrm{ZnO}$ and ${ }^{67} \mathrm{ZnO}-\mathrm{PEG}$ NPs powders. (f) Particle size distribution by intensity of colloidal dispersion of ${ }^{67} \mathrm{ZnO}-\mathrm{PEG}$ NPs in CCT, EtOH and water acquired by dynamic light scattering.

The mean hydrodynamic diameters and (polydispersity indices) of ${ }^{67} \mathrm{ZnO}-\mathrm{PEG} \mathrm{NP}$ suspensions in MQ water, ethanol (EtOH), and capric caprylic triglyceride (CCT) determined by the dynamic light scattering were $341 \mathrm{~nm}(0.162), 254 \mathrm{~nm}(0.180)$, and $248 \mathrm{~nm}$ (0.063), respectively (Figure 2f). The difference between the primary size determined by TEM and these results indicated that the NPs aggregated in the solvents: less in CCT, more so in water. Aggregation of ZnO NPs in ultra-pure MQ water is due to low ionic strength of the solvent and a lack of stabilising organic matter [51], whereas in CCT, there is reduced 
aggregation potentially due to its increased viscosity of the solvent conceivably inhibiting diffusion and particle collisions [52]. However, in aqueous solvent, the dissolution of zinc ions from bulk $\mathrm{ZnO}$ (diameter $1920 \mathrm{~nm}$ ) was reduced compared to that of ZnO NPs (20-75 nm) due to the increased surface area for dissolution available for the NPs [53]. Therefore, increasing the size of the particles through aggregation would likely decrease the dissolution of ionic zinc species [54], this effect would be reduced for CCT due to lower observed aggregation and that it is a non-aqueous solvent.

\subsection{Multiphoton Microscopy Imaging}

Multiphoton and confocal microscopy images of HSE are shown in Figure 3. SHG images (magenta) are shown in Figure 3, as observed in HSE treated with the ${ }^{67} \mathrm{ZnO}-\mathrm{PEG}$ NPs in CCT formulation (hereafter, "treated"). At the same time, no SHG signal was detected in the fluorescent channels spectrally configured for ZP1 (cyan) and zinquin (green). SHG signals were confined within the outer layers of the SC of the treated HSE, and not in the VE. Considering SHG originated exclusively from $\mathrm{ZnO}$ nanocrystals, this result indicated that no NPs penetrated the SC into VE. HSE (dermis removed) was used in these experiments to remove the inherent SHG signal of the collagen found throughout the dermis of human skin. Confocal microscopy images of the blank and treated HSE stained with zinquin and ZP1 zinc sensors are shown in Figure 3 and reported on the presence of intracellular and labile zinc species in HSE, respectively. It is important to note the positive fluorescence contrast of both zinquin- and ZP1-stained HSEs in both SC and VE. The contrast increased in the treated HSE in comparison with the blank HSE, as shown in Figure 3. Superimposed images of SHG and zinc sensors clearly delineate the distribution of ${ }^{67} \mathrm{ZnO}-\mathrm{PEG}$ NPs in SC and $\mathrm{ZnO}$ dissolution species across the treated HSE. The results of the multiphoton microscopy were also confirmed by structured illumination microscopy, as shown in Figure 4a. ${ }^{67} \mathrm{ZnO}$-PEG aggregates were detected across the superficial layers of the SC (spots marked by a yellow arrow) and no penetration was observable beyond the SC.

To evaluate the uptake of zinc species in the treated HSE, we plotted the fluorescence intensities of the zinc sensors and SHG intensity averaged over the SC and VE layers of the treated and blank HSE in Figure $4 \mathrm{~b}-\mathrm{d}$. The SHG signal was found to be negligible in the VE of both treated and blank HSE, although as expected it was significantly greater in the SC of the treated HSE in comparison with the negligible SHG in the blank HSE's SC (Figure 4b). The zinquin and ZP1 fluorescent signals were enhanced in the treated HSE in comparison with that of the blank HSE (Figure 4c,d). A statistically significant increase of the ZP1 fluorescence $(p \leq 0.05, n=7)$ in the SC of the treated HSE indicated an enhanced uptake of labile zinc species within the SC, following the dissolution of ${ }^{67} \mathrm{ZnO}$ PEG NPs. This observation is supported by the observed zinc levels in the treated SC using $X$-ray fluorescence microscopy technique [55]. It has been reported that zinc sequestration into zinc-containing proteins diminishes the ZP1 fluorescence [56]. The reduced ZP1 fluorescence in the VE of the treated and blank HSE suggests that labile Zn was sequestered by intracellular proteins in VE as shown by no increase in ZinPyr-1 intensity in Figure 3. This inference was corroborated by the increased signal in zinquin fluorescence resulting from the increase in bound intracellular zinc in the treated HSE VE. Zinquin is known to be less discriminate between free, labile and bound intracellular zinc species as it measures all intracellular zinc [57], and as such, revealed a statistically significant uptake of exogenous zinc in VE resulting from ${ }^{67} \mathrm{ZnO}-\mathrm{PEG} \mathrm{NP}$ topical application on excised skin.

We note that, in general, fluorescence assays of zinc sensors provide quantitative evaluation of the zinc concentration relative to a control which can be used for comparison between treated and blank skin samples. To assess the potential cytotoxic effects of $\mathrm{Zn}^{2+}$ and zinc species, quantitative measurements of the zinc uptake in treated and blank skin were performed [58]. 


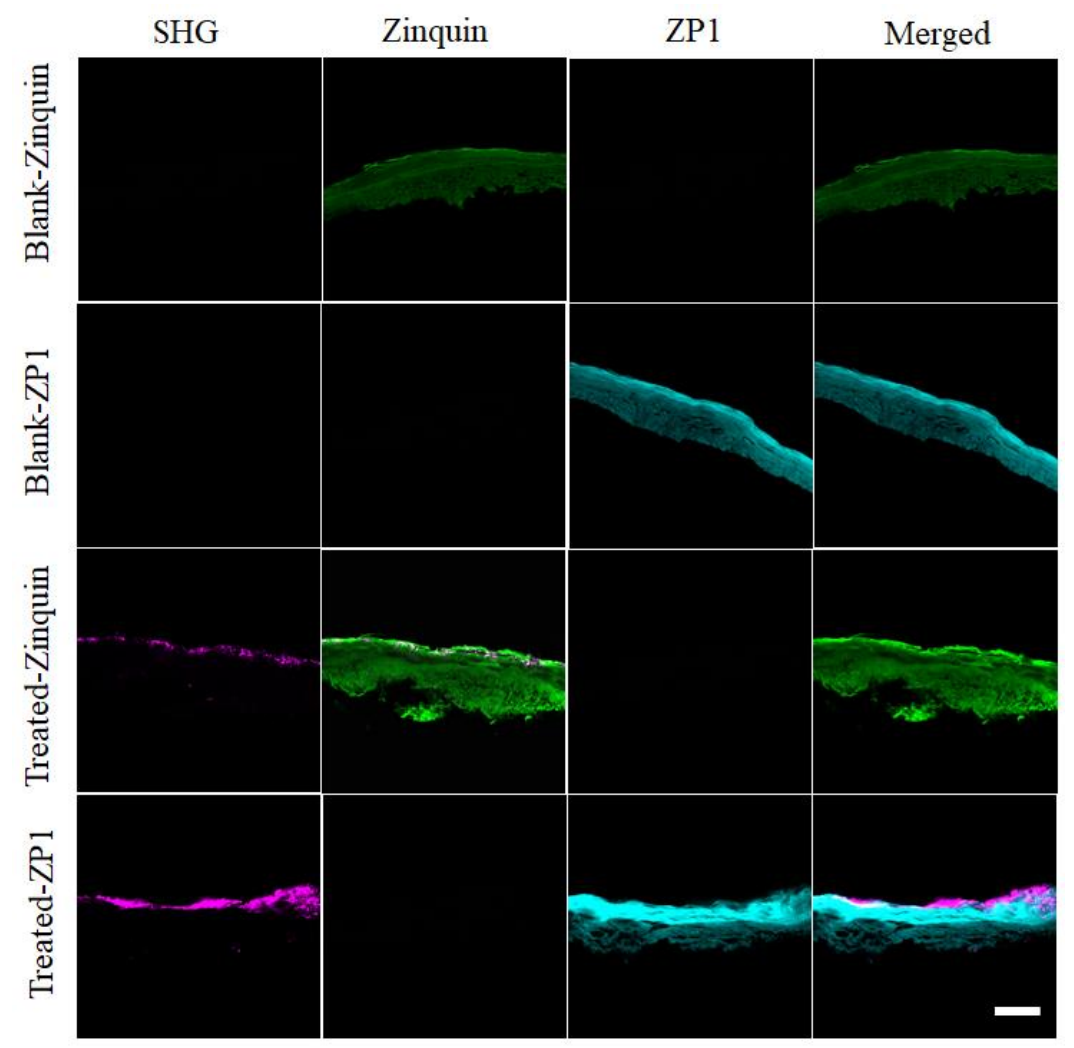

Figure 3. Multiphoton and confocal microscopy images of cross-sectioned HSEs post-treatment with either blank CCT formulation (Blank) or ${ }^{67}$ ZnO-PEG $(20 \% w t / w t)$ in CCT formulation (Treated) for $48 \mathrm{~h}$ at $35 \pm 1{ }^{\circ} \mathrm{C}$. First and second rows show the images of blank HSEs stained with zinquin and ZP1, respectively. Third and fourth rows are the images of treated HSEs stained with zinquin and ZP1, respectively. From left, first, second, third and fourth columns show images of HSEs in SHG (magenta), zinquin (green), ZP1 (cyan) and merged channels, respectively. SHG signal of nano-sized ${ }^{67} \mathrm{ZnO}-\mathrm{PEG}$ was acquired with multiphoton excitation/emission at $800 \mathrm{~nm} / 400 \mathrm{~nm}$. Zinquin signal was obtained with multiphoton excitation/emission at $740 \mathrm{~nm} / 490 \mathrm{~nm}$. For ZP1, excitation/emission was collected at $488 \mathrm{~nm} / 540-560 \mathrm{~nm}$ using a 488-nm argon laser. Scale bar, $40 \mathrm{~mm}$.

\subsection{Quantitative Measurement of Absorbed ${ }^{67} \mathrm{Zn}$ in Skin Layers by LA-ICP-MS and ICP-MS}

LA-ICP-MS analysis was carried out using cross-sectioned freshly excised full-thickness human skin treated with either blank CCT (blank skin) or ${ }^{67} \mathrm{ZnO}$-PEG NPs $(20 \% w t / w t)$ in CCT (treated skin). Figure $5 a, c$ shows the brightfield images of cross-sectioned blank and treated skin samples, respectively. The results of LA-ICP-MS analysis are presented as an elemental map of ${ }^{67} \mathrm{Zn}$ for blank (Figure $5 \mathrm{~b}$ ) and treated skin (Figure $5 \mathrm{~d}$ ). Figure 5e presents the mean concentrations of ${ }^{67} \mathrm{Zn}$ tracer in ${ }^{67} \mathrm{ZnO}-\mathrm{PEG}$ treated and blank skin sections determined by LA-ICP-MS. A considerable amount of ${ }^{67} \mathrm{Zn}$ was found in the treated skin SC. ${ }^{67} \mathrm{Zn}$ concentration, $\mathrm{C}_{67} \mathrm{Zn}$ gradually reduced from the uppermost layers downwards: $235 \pm 49 \mu \mathrm{g} / \mathrm{g}$ of dry tissue in SC to $2.0 \pm 0.5 \mu \mathrm{g} / \mathrm{g}$ in VE in the treated skin. ${ }^{67} \mathrm{Zn}$ concentration in dermis of the treated skin was measured as $0.9 \pm 0.3 \mu \mathrm{g} / \mathrm{g}$ and deemed indistinguishable from that of the blank skin dermis $(0.6 \pm 0.2 \mu \mathrm{g} / \mathrm{g})$. The concentration of exogenous zinc, $C_{e x Z n}$ in skin layers was calculated using $C_{e x Z n}=\left[C_{67} Z n\right.$ (treated) $-C_{67} Z n$ (control) $] / E_{67}$, where $E_{67}$-the enrichment factor of ${ }^{67} \mathrm{Zn}$ tracer determined in a separate ICP-MS measurement as $65.4 \pm 0.2 \%$, with the results summarised in Table 1 . 
(a)

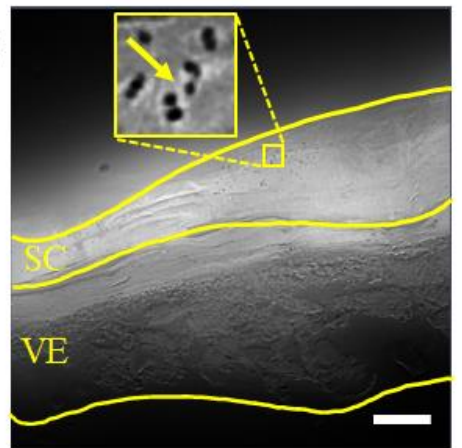

(c)

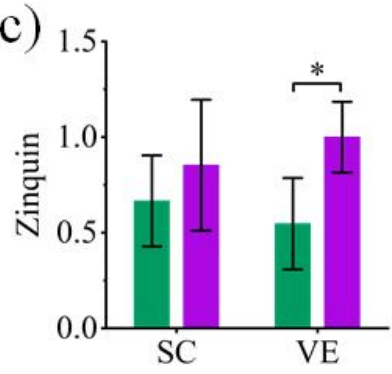

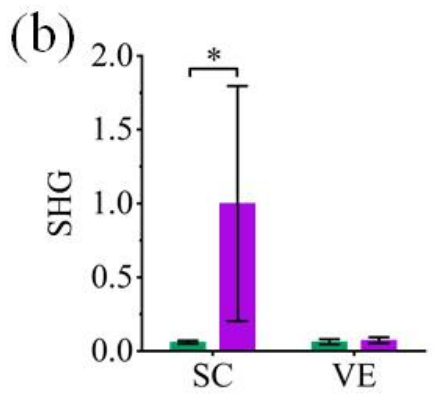

(d)

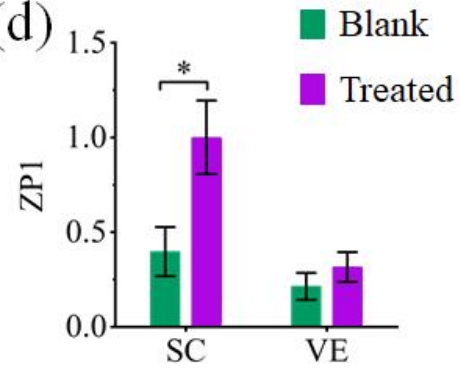

Figure 4. (a) Structured illumination microscopy image of ZnO-treated HSE. The inset is a magnified area of the image showing ${ }^{67} \mathrm{ZnO}$-PEG NPs aggregates (pointed by a yellow arrow) on SC surface. Scale bar, $5 \mu \mathrm{m}$. Results of image analysis of SHG, zinquin and ZP1 signals in untreated (Blank) and ${ }^{67} \mathrm{ZnO}$-treated-HSEs (Treated). Bar plots compare the normalised intensities (mean $\pm 95 \%$ confidence interval, $n=7$ ) of (b) SHG, (c) zinquin, and (d) ZP1 signals in SC and VE of blank and treated HSEs. $\left.{ }^{*}\right)$ shows significance difference levels at $p<0.05$.
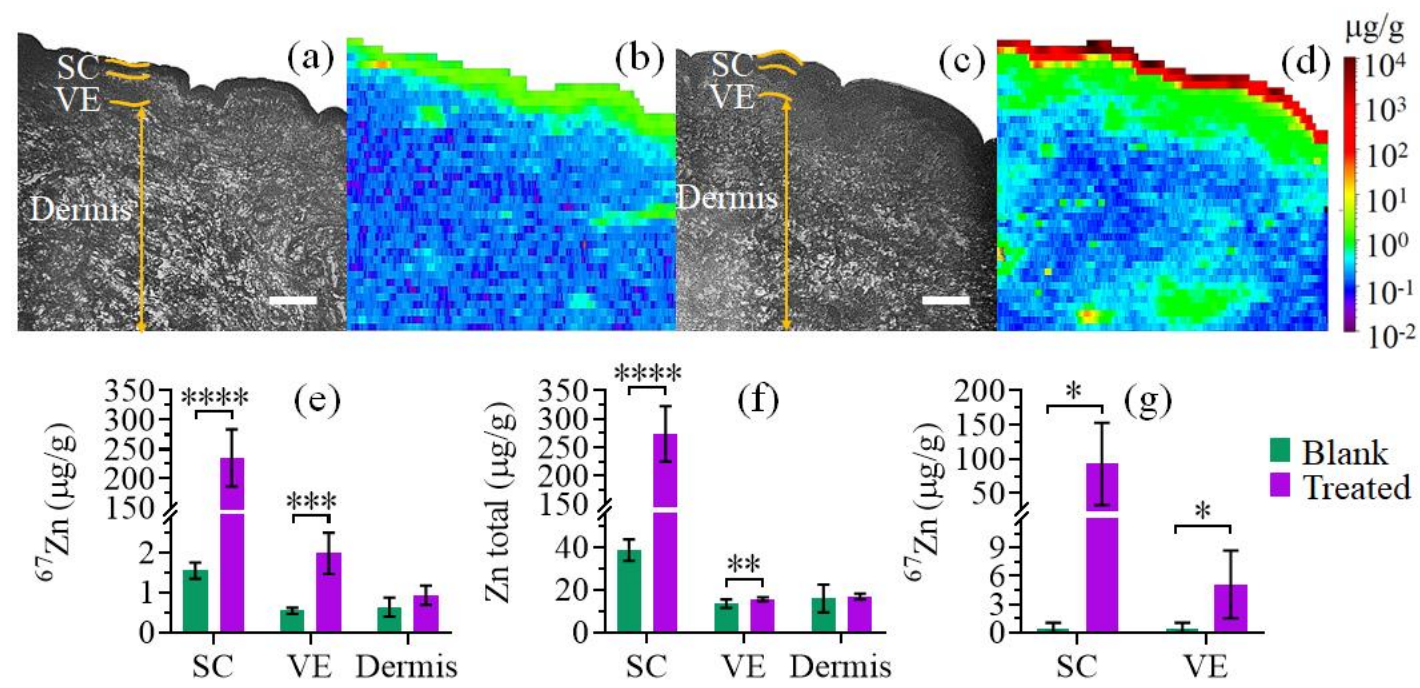

Blank

Treated

Figure 5. Results of mass spectrometry analysis of untreated and ${ }^{67} \mathrm{ZnO}-\mathrm{PEG}$ NPs treated human skin samples. (a) Brightfield image of full-thickness freshly excised human skin section post-treatment with blank CCT formulation (Blank) for $48 \mathrm{~h}$ at $35 \pm 1{ }^{\circ} \mathrm{C}$. SC, VE and Dermis designate stratum corneum, viable epidermis and dermis layers, respectively. (b) LA-ICP-MS map of ${ }^{67} \mathrm{Zn}$ concentration $(\mu \mathrm{g} / \mathrm{g})$ of (a). (c) Brightfield image of full-thickness freshly excised human skin section post-treatment with ${ }^{67} \mathrm{ZnO}$-PEG NPs $(20 \% w t / w t)$ in CCT formulation (Treated) for $48 \mathrm{~h}$ at $35 \pm 1{ }^{\circ} \mathrm{C}$. (d) LA-ICP-MS map of ${ }^{67} \mathrm{Zn}$ concentration $(\mu \mathrm{g} / \mathrm{g})$ of $(\mathbf{c})$. (e) ${ }^{67} \mathrm{Zn}$ and (f) total zinc concentrations in skin measured by LA-ICP-MS for blank and treated samples. (g) ${ }^{67} \mathrm{Zn}$ concentration measured by solution-based ICP-MS for untreated and treated HSEs. $\left({ }^{*}\right)$, $\left.{ }^{* *}\right),\left({ }^{* *}\right)$ and $\left.{ }^{* * * *}\right)$ show significance difference levels at $p<0.05, p<0.01, p<0.001$ and $p<0.0001$, respectively. Data are presented as mean $\pm 95 \%$ confidence interval, $n^{3} 4$. Scale bars are $200 \mu \mathrm{m}$. 
Table 1. Summary of the measured and calculated zinc values in human skin.

\begin{tabular}{|c|c|c|c|c|c|c|}
\hline & $\begin{array}{l}C_{67} \mathrm{Zn}^{\prime} \\
\mu \mathrm{g} / \mathrm{g}\end{array}$ & $\begin{array}{c}C_{e x Z n}, \\
\mu \mathrm{g} / \mathrm{g}\end{array}$ & $\begin{array}{c}C_{e n Z n,} \\
\mu \mathrm{g} / \mathrm{g}\end{array}$ & $\begin{array}{c}C_{e x Z n} \\
\mu \mathrm{g} / \mathrm{mL}\end{array}$ & $\begin{array}{l}C_{e n Z n}, \\
\mu \mathrm{g} / \mathrm{mL}\end{array}$ & $\begin{array}{c}\mathrm{IC}_{50}{ }^{*} \\
\mu \mathrm{g} \mathrm{Zn} / \mathrm{mL}\end{array}$ \\
\hline SC & $235 \pm 49$ & $360 \pm 70$ & $39 \pm 5$ & $120 \pm 23$ & $13 \pm 2$ & - \\
\hline VE & $2.0 \pm 0.5$ & $3.1 \pm 0.8$ & $13 \pm 2$ & $1.0 \pm 0.3$ & $4.3 \pm 0.7$ & - \\
\hline Dermis & $0.9 \pm 0.3$ & $1.4 \pm 0.5$ & $16 \pm 7$ & $0.5 \pm 0.2$ & $5 \pm 2$ & - \\
\hline HaCaT cells & - & - & - & - & - & $26 \pm 5$ \\
\hline
\end{tabular}

${ }^{*}$ cytotoxicity of ${ }^{67} \mathrm{ZnO}-\mathrm{PEG}$ NPs, equivalent to $25 \mu \mathrm{g} / \mathrm{mL}$ of ${ }^{67} \mathrm{ZnO}$ NPs.

The endogenous concentration of ${ }^{67} \mathrm{Zn}$ tracer in blank skin VE was found to be $C_{67} Z_{n}$ (control) $=0.5 \pm 0.1 \mu \mathrm{g} / \mathrm{g}$ from where the concentration of endogenous total zinc, $C_{e n Z n}$ was estimated using $C_{e n Z n}=C_{67} \mathrm{Zn}$ (control) $/ A_{67}$, where $\mathrm{A}_{67}$ represents the natural abundance of ${ }^{67} \mathrm{Zn}$ isotope tabulated as $4.04 \%$ [59]. The total zinc concentrations in SC, VE and dermis of blank skin were estimated as $39 \pm 5 \mu \mathrm{g} / \mathrm{g}, 13 \pm 2 \mu \mathrm{g} / \mathrm{g}$, and $16 \pm 7 \mu \mathrm{g} / \mathrm{g}$ respectively. This represents an approximately ten-fold increase in the elemental zinc amount accumulated in SC of treated skin $\left(\mathrm{C}_{67} \mathrm{Zn}\right.$ (treated) $\left.=235 \pm 49 \mu \mathrm{g} / \mathrm{g}\right)$ because of the $\mathrm{ZnO} \mathrm{NP}$ sunscreen application, with the exogenous zinc combined as $\mathrm{ZnO} N P$ aggregates, $\mathrm{Zn}^{2+}$ and zinc species. In VE of the treated skin, we detected a statistically significant increase of the total zinc concentration by ca. $23 \%$ (Figure $5 \mathrm{f}$ ), the exogenous zinc fraction comprised $\mathrm{Zn}^{2+}$ probably existed in protein-bound forms. The exogenous zinc accumulation in dermis was statistically insignificant.

The measured concentration of endogenous epidermal zinc $13 \pm 2 \mu \mathrm{g} / \mathrm{g}$ does fall in the range of the reported values [25], but these values vary widely, ranging from 3 to $60 \mu \mathrm{g} / \mathrm{g}$ depending on the analysis technique [26,60]. To validate our results reported here, we carried out a separate experiment to assay $C_{e n Z n}$, using homogenised untreated human skin by using "gold standard" quantitative technique ICP-MS and its modality LA-ICP-MS (see Section S2, Supplementary Materials). $C_{e n Z n}$, measured by ICP-MS was $15 \pm 4 \mu \mathrm{g} / \mathrm{g}$. $\mathrm{C}_{e n Z n}$ measured by LA-ICP-MS averaged over several sites of the homogenised human skin sample was $11 \pm 8 \mu \mathrm{g} / \mathrm{g}$. $C_{e n Z n}$ measured by ICP-MS and LA-ICP-MS were consistent with each other and consistent with the value of $13 \pm 2 \mu \mathrm{g} / \mathrm{g}$ reported here underpinning the reliability of our results.

To validate the results obtained by LA-ICP-MS of cross-sectioned freshly excised skin, we carried out solution-based ICP-MS of tape-stripped HSEs, with the results presented in Figure 5g. Most of the ${ }^{67} \mathrm{Zn}$ tracer was recovered within the wash $(630 \pm 110 \mu \mathrm{g} / \mathrm{g})$ and is therefore considered unabsorbed. In comparison with the blank HSE, a significant increase of ${ }^{67} \mathrm{Zn}$ in the treated SC was detected in good agreement with the data by the LA-ICP-MS analysis and fluorescence zinc assays (c.f. Figure 3$).{ }^{67} \mathrm{Zn}$ recovered from the remaining VE after tape-stripping was ca. 4000-fold greater in the treated HSE compared to the blank, amounted to $C_{67} \mathrm{Zn}=4.5 \pm 4.0 \mu \mathrm{g} / \mathrm{g}$. This value was almost twice of $C_{67} \mathrm{Zn}$ in VE measured by LA-ICP-MS. This discrepancy was attributed to incomplete removal of the SC containing ZnO NPs from the HSE due to an insufficient number of tape-strips-we applied 3 tape-strips due to the HSE frailty in comparison with the required number of 20 or even 40 tape-strips [61]. Therefore, $C_{e x Z n}$ in VE of the treated HSE derived from the ICP-MS data was overestimated. Ex vivo human skin used in the ICP-MS study was not viable, and therefore the skin's innate zinc homeostatic system was impaired, including active transport of an excess of zinc to peripheral microcirculation. The amount of ${ }^{67} \mathrm{Zn}$ found in the receptor fluid of the treated samples was comparable with that of the background and indicated that no significant amount of topically applied ${ }^{67} \mathrm{Zn}$ permeated across the HSE to the receptor fluid during the 48-h observation period.

Our results offer an insight into how zinc appeared in the systemic circulation, following $\mathrm{ZnO}$ NP sunscreen topical application on volunteer's human skin [46]. The elevated ${ }^{67} \mathrm{Zn}$ levels could be found within the furrows and superficial layers of the SC, which were attributed to undissolved ${ }^{67} \mathrm{ZnO}$-PEG NPs. At the same time, the SC of skin contains a significant amount of keratin characterised by abundant sulfhydryl groups of proteins [62]. 
The high binding propensity of these groups to labile zinc could contribute to the significant $\mathrm{Zn}$ concentration detected in the SC. We speculate that the high amount of $\mathrm{Zn}$ in the SC acted as a depot for the epidermal permeation of zinc. Previously, this depot led to a long lag of 5 days for the systemic absorption of zinc in human volunteers [46]. Our LA-ICP-MS, ICP-MS and multiphoton microscopy data were consistent and indicative of the presence of the elevated exogenous $\mathrm{Zn}$ levels in the VE layers stemmed from $\mathrm{Zn}$ species desorbed from $\mathrm{ZnO}$ NP-based sunscreen.

\subsection{Cytotoxicity of ${ }^{67} \mathrm{ZnO}-\mathrm{PEG}$ NPs in HaCaT Cells}

Zinc has specific roles in skin functions and can be detrimental or toxic if present in excessive amounts [63]. The detected $\mathrm{Zn}$ species raised a question of whether the excess of zinc that permeates the skin is cytotoxic to keratinocytes within the VE or not? To determine $\mathrm{ZnO} N P$ cytotoxicity to keratinocytes, we performed cell viability assays versus $\mathrm{Zn}$ concentration. To compare $\mathrm{IC}_{50}$ value expressed in terms of $\mu \mathrm{g} / \mathrm{mL}$ with the values in terms of $\mu \mathrm{g}$ of ${ }^{67} \mathrm{Zn}$ per gram of dry tissue ( $\left.\mu \mathrm{g} / \mathrm{g}\right), \mu \mathrm{g} / \mathrm{g}$ units were converted to $\mu \mathrm{g} / \mathrm{mL}$ by using the reported value of the water content in VE (ca. 70\%) (see Section S3, Supplementary Materials) [64]. Figure 6a shows data taken from Figure $5 \mathrm{f}$ and replotted versus $\mu \mathrm{g} / \mathrm{mL}$, while the exogenous ${ }^{67} \mathrm{Zn}$ concentrations in VE and dermis were recalculated as $1.0 \pm 0.3 \mu \mathrm{g} / \mathrm{mL}$ and $0.5 \pm 0.2 \mu \mathrm{g} / \mathrm{mL}$, respectively.
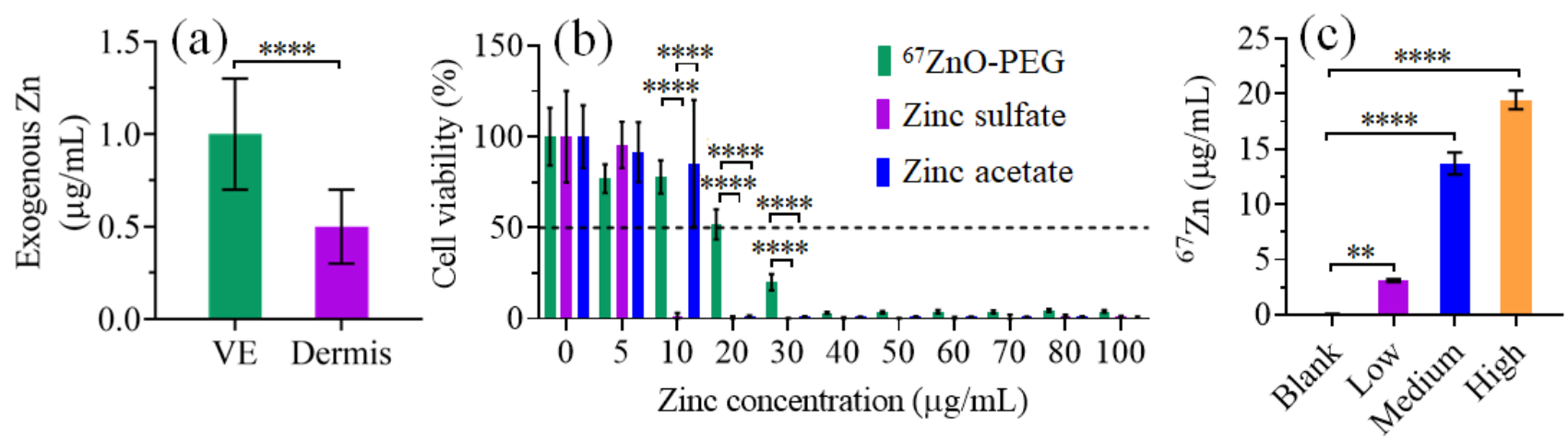

Figure 6. (a) Exogenous $C_{67} \mathrm{Zn}$ expressed in $\mu \mathrm{g} / \mathrm{mL}$, as assayed by LA-ICP-MS in VE and dermis layers (replotted from Figure 5f). (b) HaCaT cell viability exposed to zinc acetate, zinc sulphate, and ${ }^{67} \mathrm{ZnO}-\mathrm{PEG}$ NPs for $24 \mathrm{~h}$. The data format: mean \pm SD for $n=8$ replicates. (c) $C_{67} \mathrm{Zn}$ from supernatant of $\mathrm{HaCaT}$ cell-mediated culture media on addition of ${ }^{67} \mathrm{ZnO}$ PEG NPs measured by ICP-MS. Blank, Low, Medium and High stand for cell incubation with 0, 5, $25 \mathrm{and} 50 \mu \mathrm{g} / \mathrm{mL}$ of ${ }^{67} \mathrm{ZnO}-\mathrm{PEG}$ NPs, respectively. The data format: mean $\pm \mathrm{SD}, n=3$. $\left.{ }^{* *}\right)$ and $\left(^{* * *}\right)$ show significance difference levels at $p<0.01$ and $p<0.0001$, respectively.

Figure $6 \mathrm{~b}$ presents the results of the MTT assay of keratinocyte cells (HaCaTs) treated with ionic $\mathrm{Zn}$ sources, zinc acetate, zinc sulphate, as well as ${ }^{67} \mathrm{ZnO}$-PEG NPs, in the concentration range of $0-100 \mu \mathrm{g} / \mathrm{mL}$. The applied concentrations were expressed in terms of the equivalent concentrations of $\mathrm{Zn}$. $\mathrm{Zn}$ salts and ${ }^{67} \mathrm{ZnO}$-PEG NPs were not cytotoxic at a concentration of $<5 \mu \mathrm{g} \mathrm{Zn} / \mathrm{mL}$, although the cell viability was slightly less for ${ }^{67} \mathrm{ZnO}-\mathrm{PEG}$ NPs at this concentration. The cell viability dropped at 5-10 $\mu \mathrm{g} \mathrm{Zn/mL} \mathrm{and} \mathrm{10-20} \mu \mathrm{g} \mathrm{Zn/mL}$ for zinc sulphate and zinc acetate, respectively. The greater cytotoxicity of zinc sulphate observed here was corroborated by in vitro studies using PC12 cells and explained by the greater cellular uptake of zinc [65]. The cytotoxicity of ${ }^{67} \mathrm{ZnO}$-PEG NPs was characterised by $\mathrm{IC}_{50}=26 \pm 5 \mu \mathrm{g} \mathrm{Zn} / \mathrm{mL}$ (equivalent to $25 \mu \mathrm{g} / \mathrm{mL}$ of ${ }^{67} \mathrm{ZnO} \mathrm{NPs}$ ), and appeared less in comparison with that of $Z n$ salts in agreement with literature $[66,67]$.

IC50 of ${ }^{67} \mathrm{ZnO}-\mathrm{PEG}$ NPs assayed in complete cell culture medium is not directly comparable with $C_{e x Z n}$ assayed in VE by LA-ICP-MS, because foetal bovine serum (FBS) supplement in cell cultures and extracellular matrix in skin mediates ${ }^{67} \mathrm{ZnO}-\mathrm{PEG} \mathrm{NP}$ interaction with keratinocytes via two processes. Firstly, $\mathrm{ZnO} N P$ solubility depends on the matrix of culture medium [53]. In general, $\mathrm{ZnO} N$ P solubility is high in an aqueous solution, 
yielding mostly $\mathrm{Zn}^{2+}$, with almost complete dissolution achieved at $<10 \mu \mathrm{g} / \mathrm{mL}$. Secondly, a fraction of the dissolved $\mathrm{Zn}^{2+}$ species is sequestered by serum proteins or ligands thus reducing the concentration of potentially cytotoxic species-free zinc. For example, albumin added to complete culture medium in molar excess to $\mathrm{Zn}^{2+}$ markedly reduced labile $\mathrm{Zn}^{2+}$ to the $\mathrm{nM}$ range [68] and addition of bovine serum albumin or EDTA to culture media can chelate excess labile zinc reducing cytotoxicity of zinc species to HaCaT cells [41]. It has been reported that $20 \mu \mathrm{g} / \mathrm{mL}$ of $\mathrm{ZnO} N P$ yielded $\sim 5 \mu \mathrm{g} / \mathrm{mL}$ of free zinc in complete cell culture media (RPMI1640 supplemented with $10 \%$ FBS) and equilibrated at $>40 \mu \mathrm{g} / \mathrm{mL}$ of $\mathrm{ZnO}$ NPs to yield $10 \mu \mathrm{g} / \mathrm{mL}$ of free zinc [24].

We investigated the production of potentially cytotoxic species in complete culture medium (DMEM $+10 \%$ FBS) qualitatively and quantitatively by fluorescent zinc sensor (ZP1) and ICP-MS assays, respectively. HaCaT cells in DMEM + 10\% FBS were dosed with Blank, Low $(5 \mu \mathrm{g} / \mathrm{mL})$, Medium $(25 \mu \mathrm{g} / \mathrm{mL})$ and High $(50 \mu \mathrm{g} / \mathrm{mL})$ concentrations of ${ }^{67} \mathrm{ZnO}$ NPs for $24 \mathrm{~h}$, followed by ultracentrifugation to remove cells and serum proteins. The resultant supernatants containing $\mathrm{Zn}^{2+}$ and zinc species bound to low molecular weight ligands (termed here, labile zinc, laZn) were assayed. Qualitative evaluation of $C_{l a Z n}$ based on the fluorescent intensities of zinc sensor ZP1 in the complete cell culture medium (Figure S3) indicated a monotonic increase of the concentration of labile zinc versus the dosed amount of ${ }^{67} \mathrm{ZnO}$ and supported the increased cytotoxicity versus concentration of zinc oxide nanoparticle reported previously [24].

The results of the ICP-MS assay of $C_{67} \mathrm{Zn}$ are presented in Figure 6c. The concentration of $C_{l a Z n}$ can be calculated by using equation $C_{l a Z n}=C_{67} Z_{n} / E_{67}$. The low dosing $(5 \mu \mathrm{g} / \mathrm{mL}$ of ${ }^{67} \mathrm{ZnO}$-PEG NPs) resulted in a 60 -fold increase of $C_{l a Z n}$ and corresponded to an $\sim 25 \%$ viability drop (c.f. Figure $6 \mathrm{~b}$ ). The high dosing $(50 \mu \mathrm{g} / \mathrm{mL})$ yielded $C_{l a Z n}=31 \pm 2 \mu \mathrm{g} / \mathrm{mL}$ $\left(C_{67} \mathrm{Zn}_{n}=20 \pm 1 \mu \mathrm{g} / \mathrm{mL}\right)$ and reduced the cell viability to $\sim 50 \%$ level (c.f. Figure $\left.6 \mathrm{~b}\right)$. Medium to high dosing range yielded a narrow $C_{l a Z n}$ range of $21-31 \mu \mathrm{g} / \mathrm{mL}\left(C_{67} \mathrm{Zn}, 14-20 \mu \mathrm{g} / \mathrm{mL}\right)$ also seen in Figure S3 - but resulted in a dramatic viability drop from $\sim 50 \%$ to $2 \%$, as obvious in Figure $6 \mathrm{~b}$ within the $C_{Z n}$ range of $20-50 \mu \mathrm{g} / \mathrm{mL}$. This suggests that the $\mathrm{Zn}$ threshold for significant cell toxicity within the culture media falls between $C_{l a Z n}$ range of $21-31 \mu \mathrm{g} / \mathrm{mL}$ per addition of $25-50 \mu \mathrm{g} / \mathrm{mL}^{67} \mathrm{ZnO}-\mathrm{PEG} \mathrm{NP}$.

\subsection{Discussion}

The main objective of this study was to quantify the amounts of labile zinc within the VE after topical application of ZnO NPs to excised human skin. For the first time, to the best of our knowledge, the concentration of exogenous $\mathrm{Zn}$ ions in viable epidermis of human skin was measured using a rare stable ${ }^{67} \mathrm{Zn}$ isotope tracing technique and benchmarked against the cytotoxicity threshold to support a notion of $\mathrm{ZnO}$ sunscreen safety. We observed that ${ }^{67} \mathrm{ZnO}$-PEG NPs were localised and retained in the superficial layers of the SC and did not penetrate further into the VE. A statistically significant increase in the signal intensity of a labile zinc-specific probe (ZP1) post ${ }^{67} \mathrm{ZnO}$-PEG NP application within the SC and a statistically significant increase in the signal intensity of an intracellular zinc probe (zinquin) within the VE supports our hypothesis that zinc species from ZnO NP permeated across the SC to the VE. While most of the zinc was not absorbed percutaneously, an increase of labile zinc was found within the VE and could therefore cause localised toxicity or become systemically available. However, the cytotoxicity is dependent on the speciation of the zinc, its sequestration by extracellular proteins and cellular uptake. We measured $\mathrm{Zn}$ concentrations in the VE and crucially found that it was ca. $>25$-fold lower than the cytotoxicity threshold for ${ }^{67} \mathrm{ZnO}$-PEG NPs. Furthermore, ZnO NPs did not permeate beyond the $\mathrm{SC}$ barrier to the viable keratinocytes, thus evading physical damage caused by the NPs to the cell membranes [69].

The ${ }^{67} \mathrm{Zn}$ concentration recovered between the IC50 and IC90 concentrations of $\mathrm{ZnO}$ PEG NPs in vitro was found to be significantly, at least 15 times, higher than the exogenous zinc concentration permeated within the VE. Interestingly, Yamada et al. [18] estimated that the human epidermal $\mathrm{Zn}$ concentrations after a maximum FDA-approved $\mathrm{ZnO} \mathrm{NP}$ 
dose in a sunscreen product is about 10 to 50 times lower than that causing toxicity in human epidermal cells. While intact human skin shows a good safety profile it may not stand for an impaired skin barrier as previous work has shown that dissolved zinc species can significantly increase within the VE after topical application of ZnO NPs to impaired excised human skin [40]. We did not evaluate the dissolution of uncoated ZnO NPs versus PEG-ZnO NPs specifically. According to the literature, the aqueous solubility of PEGcoated $\mathrm{ZnO}$ is comparable to that of uncoated $\mathrm{ZnO}$ nanoparticles. However, in cell culture medium (RPMI-1640) supplemented with FBS, the solubility of $\mathrm{ZnO}$ is almost twice that of PEG-ZnO nanoparticles [70].

\section{Material and Methods}

\subsection{Synthesis of ${ }^{67} \mathrm{ZnO}-\mathrm{PEG}$ NPs via a Co-Precipitation Method}

All reagents were of analytical grade and used as received without further purification. Acetic acid $\left(\mathrm{CH}_{3} \mathrm{CO}_{2} \mathrm{H}, \geq 99.7 \%\right)$, poly(ethylene glycol) (PEG; average molecular weight $200 \mathrm{Da})$, potassium hydroxide $(\mathrm{KOH}, \geq 85 \%)$, cyclohexane $(99.5 \%)$, isopropyl alcohol ( $\geq 99.7 \%)$, acetone $(\geq 99.5 \%)$, were obtained from Sigma-Aldrich Chemicals (Sydney, NSW, Australia). Ethanol (EtOH; 100\% undenatured) was supplied from Chem-Supply (Adelaide, $\mathrm{SA}$, Australia). Micron-sized $\mathrm{ZnO}$ powder enriched to $>65 \%{ }^{67} \mathrm{Zn}$ and a chemical purity $>99.96 \%$ was supplied by FSUE Integrated Plant Electrohimpribor (Lesnoy, Russia), and produced by an electromagnetic enrichment method (calutron).

A top-down chemical approach based on the co-precipitation method was used to etch ${ }^{67} \mathrm{ZnO}$ micrometre-scale particles to nanoscale ${ }^{67} \mathrm{ZnO}$ particles (see Supplementary Materials, Section S1, for details). The precursor concentrations and time were optimised by using commercial $\mathrm{ZnO}$ powder. Briefly, as-received ${ }^{67} \mathrm{ZnO}$ micro-particles were mixed with acetic acid at the molar ratio of $1: 2$ heated to $50{ }^{\circ} \mathrm{C}$ to produce enriched zinc acetate ${ }^{67} \mathrm{Zn}(\mathrm{Ac})_{2}$ salt, which was dried at the same temperature for $2 \mathrm{~h}$. Then, $10 \mathrm{~mL}$ of $0.1-\mathrm{M}^{67} \mathrm{Zn}(\mathrm{Ac})_{2}$ was mixed with 0.7-mL PEG and stirred for $30 \mathrm{~min}$ at room temperature. Then, $5 \mathrm{~mL}$ of $1 \mathrm{M} \mathrm{KOH}$ solution was added dropwise and stirred at room temperature to obtain white gel, which was transferred to a water bath preheated to $75^{\circ} \mathrm{C}$. The precipitate of formed ${ }^{67} \mathrm{ZnO}-\mathrm{PEG}$ NPs was heated for $1 \mathrm{~h}$ to complete the reaction. The precipitate was collected and washed several times with $\mathrm{EtOH}$.

To produce sunscreen formulation mimicking commercially available sunscreens, $20 \%$ ${ }^{67} \mathrm{ZnO}-\mathrm{PEG}(w t / w t)$ was mixed with capric caprylic triglyceride (CCT). To this aim, EtOH solution of ${ }^{67} \mathrm{ZnO}-\mathrm{PEG}$ NPs was centrifuged at 10,000 rpm for $10 \mathrm{~min}$, and re-dispersed in isopropyl alcohol, followed by re-dispersion in acetone, cyclohexane, and finally in CCT.

\subsection{Characterisation of ${ }^{67} \mathrm{ZnO}-\mathrm{PEG} N \mathrm{NS}_{\mathrm{S}}$}

The size and morphology of micrometre and nanometre-scale ${ }^{67} \mathrm{ZnO}$ materials were determined by TEM (PhilipsCM10, Eindhoven, The Netherlands) operated at the accelerating voltage of $100 \mathrm{kV}$. To prepare the TEM sample, ${ }^{67} \mathrm{ZnO}$ dry powder was dispersed in $\mathrm{EtOH}$ in the concentration of $1 \mathrm{mg} / \mathrm{mL}$, dropped on a copper grid and allowed to dry. The crystal structure of as-synthesised ${ }^{67}$ ZnO-PEG NPs was determined by an X-ray diffractometer (PANalytical X'Pert Pro MPD) with a $\mathrm{Cu} \mathrm{K} \alpha$ X-ray radiation source at the characteristic wavelength of $1.5418 \AA$. The data were collected over an angular range of $10-80^{\circ}$, step size $0.017^{\circ}$. The hydrodynamic diameter and polydispersity index of ${ }^{67} \mathrm{ZnO}-$ PEG NPs dispersed in CCT, EtOH and MQ water in polystyrene cuvettes (Sigma-Aldrich, Sydney, NSW, Australia) were measured using a dynamic light scattering instrument (DLS; Zetasizer NS, Malvern, UK). ${ }^{67} \mathrm{ZnO}$ NPs in $\mathrm{CCT}, \mathrm{EtOH}$, and MQ water were prepared at the concentration of $1 \mathrm{mg} / \mathrm{mL}$ and sonicated for $30 \mathrm{~min}$.

\subsection{Preparation of Heat-Separated Human Epidermis Samples}

Human skin patches were excised from female donors ( $n=3$, aged 46-53 years) undergoing abdominoplasty surgical procedures. Prior to the research, informed written consent was obtained from all participants (The Queen Elizabeth Hospital, ethics approval 
protocol-2009208). The subcutaneous fat was removed by blunt dissection, and the skin samples were placed in a water bath at $60^{\circ} \mathrm{C}$ for $90 \mathrm{~s}$ to separate the epidermis from the dermis. The human skin epidermis (HSE) was then floated on water and placed onto a filter paper to dry. The processed HSE samples were kept in ziplock bags at $-20^{\circ} \mathrm{C}$ and were used within 6 months.

\subsection{Skin Penetration Assay}

After thawing HSE, if necessary, 3-cm-diameter disks were cut out from the skin patches and mounted on static Franz diffusion cells. The receptor and donor chambers were filled with $3.5 \mathrm{~mL}$ and $1 \mathrm{~mL}$ of PBS buffer ( $\mathrm{pH} 7.4$ ), respectively, and placed in a water bath at $35^{\circ} \mathrm{C}$ for $30 \mathrm{~min}$ to equilibrate. The transepithelial electrical resistance was measured $(>20 \mathrm{~kW})$ to ensure the HSE sample integrity according to Cross et al. [28]. To measure transepidermal water loss, PBS buffer was removed from the donor chamber and the skin surface was blotted dry. The measurements were carried out using an Aquaflux instrument (Biox Systems, London, UK) at $23.2{ }^{\circ} \mathrm{C}$ and $44.5 \%$ humidity to select HSE membranes with values $<40 \mathrm{~g} / \mathrm{m}^{2} / \mathrm{h}$ to ensure the skin barrier integrity. The PBS buffer was removed and replaced with $3.5 \mathrm{~mL}$ of HEPES buffer that was used as receptor fluid.

The HSEs were dosed at $2 \mathrm{mg} / \mathrm{cm}^{2}$ of either $20 \% w t / w t^{67} \mathrm{ZnO}-\mathrm{PEG}$ NPs in CCT or CCT labelled as treated and blank, respectively, and then incubated at $35 \pm 1{ }^{\circ} \mathrm{C}$ on a submersible magnetic stirrer for $48 \mathrm{~h}$. We covered HSE surface by the formulation entirely avoiding direct contact with the skin sample. The decreased viscosity of the sunscreen formulation at $35{ }^{\circ} \mathrm{C}$ facilitated the uniform spreading. $0.5 \mathrm{~mL}$ of the receptor solution was sampled at time points $0,0.5,2,4,8,24$, and $48 \mathrm{~h}$, and the receptor solution was replenished. The unabsorbed ${ }^{67} \mathrm{ZnO}-\mathrm{PEG}$ formulation was washed away after $48 \mathrm{~h}$ using a natural sponge immersed in PBS and then blotted dry.

Dried HSEs were weighed, and a tape stripping procedure was then performed three times to remove most of SC [71]. Tape strips, remaining HSE and wash sponges were weighed and transferred to labelled acid-resistant tubes to be digested for ICP-MS analysis.

\subsection{Sample Preparation for Microscopy}

Human HSE was used in the microscopy experiments to remove the collagen within the dermis that emits the same SHG signal as ZnO NPs. HSEs were cut into $2 \times 2 \mathrm{~mm}^{2}$ pieces and embedded in optimal cutting temperature medium, which were then snapfrozen at $-80{ }^{\circ} \mathrm{C}$, sectioned into 10- $\mu$ m-thick slices using a cryostat (Leica. CM 1950, Nussloch, Germany) and mounted on poly L-lysine-coated microscope slides. The slide mounted HSE samples were stained with $10 \mu \mathrm{L}$ of $\mathrm{ZP} 1$ or zinquin following a protocol reported elsewhere [31]. An excess of the staining solution was removed after $10 \mathrm{~min}$ and rinsed twice with ultrapure MQ water. Finally, the sections were covered with coverslips and sealed for microscopy observations.

\subsection{Multiphoton Laser-Scanning Microscopy}

Stained HSE sections were imaged using a Zeiss LSM710 multiphoton microscope equipped with an argon gas laser $(488 \mathrm{~nm})$ and a tuneable titanium-sapphire femtosecond pulsed laser (Mai Tai, Spectra Physics, Stahnsdorf, Germany). A high numerical aperture objective $\left(40 \times /\right.$ NA1.1) was used. The SHG signal of dispersed ${ }^{67} \mathrm{ZnO}-\mathrm{PEG}$ NPs in CCT was detected at $400 \mathrm{~nm}$ by using the excitation at $800 \mathrm{~nm}(6.3 \mathrm{~mW})$. The limit of quantification (LOQ) of ZnO NPs was previously determined by Leite-Silva et al. [33]. $\mathrm{ZP1}$ and zinquin fluorescent sensors were excited by the argon $(488 \mathrm{~nm}(0.7 \mu \mathrm{W}))$ and femtosecond (740 nm $(6.3 \mathrm{~mW})$ ) lasers, with emission detected at $540 \mathrm{~nm}-560 \mathrm{~nm}$ and 490 $\mathrm{nm}$, respectively. To achieve two-fold spatial resolution, super-resolution microscopy was carried out using a structured illumination module Zeiss Elyra PS.1 integrated into the laser-scanning confocal microscope using PlanAPOCHROMAT 100×/1.46 oil-immersion objective. For each condition, 3 samples were imaged. Image analysis was conducted using Image-J and ZEN lite software (Sigma-Aldrich, Sydney, NSW, Australia). 


\subsection{LA-ICP-MS Analysis}

Freshly excised abdominal human skins were received from female donors $(n=3$, aged 27-47 years) who had undergone abdominoplasty surgery. Before the research, informed written consent was obtained from all participants (The Macquarie University Hospital, ethics approval protocol-5201200935). The skin samples were processed for the subcutaneous fat removal and used for permeation assay on the same day. The permeation assay was performed using the same Franz cells set-up and formulations described in Section 3.4, with the incubation time changed to $24 \mathrm{~h}$. Afterwards, untreated (blank) and treated skin samples were snap frozen and cut into $50-\mu \mathrm{m}$ slices perpendicular to the skin surface, mounted on a glass slide and placed in a clean container to avoid contamination. Ultimate care was taken to cut the samples to avoid smearing the remnant sunscreen across the sample. In situ measurement of ${ }^{67} \mathrm{Zn}$ concentration in the skin samples was carried out using a Photon-Machines Analyte Excite 193 nm Excimer laser ablation system with Helex II sample chamber coupled to an Agilent $7700 \times$ quadrupole ICP-MS system at Macquarie Geoanalytical (MQGA) Centre, Macquarie University. Helium was used as the carrier gas (flow rate, $0.8 \mathrm{~L} / \mathrm{min}$ ) mixed with argon (flow rate, $0.8 \mathrm{~L} / \mathrm{min}$ ) before introducing it to a torch in ICP-MS. To quantify the LA-ICP-MS measurement, a spiked gelatine sample with a defined concentration of ${ }^{67} \mathrm{Zn}(10 \mu \mathrm{g} / \mathrm{g})$ was produced as described elsewhere [72] and used as standards to quantify ${ }^{67} \mathrm{Zn}$ concentrations in skin. The ${ }^{67} \mathrm{Zn}$-spiked gelatine samples were collected for acid digestion and their ${ }^{67} \mathrm{Zn}$ concentrations were determined accurately and precisely using Solution-nebulisation ICP-MS. A carbon isotope ${ }^{13} \mathrm{C}$ was used as the internal standard to correct for differences in the ablation yield of the materials, plasma condition, and instrumental drift. Laser energy of $2.11 \mathrm{~J} / \mathrm{cm}^{2}$ and a repetition rate of $10 \mathrm{~Hz}$ were used to maintain an adequate signal-to-noise ratio of ${ }^{13} \mathrm{C}$. LA-ICP-MS was operated in a line-scan mode by rastering a square spot $35 \times 35 \mu \mathrm{m}^{2}$ at the $35 \mu \mathrm{m} / \mathrm{s}$ scan rate. The data compression was carried out using software Iolite (version 3.6).

\subsection{Sample Preparation for Solution Nebulisation ICP-MS}

The collected receptor fluid samples, natural sponges from the wash, remaining HSEs, tape strips and gelatine standard were prepared for ICP-MS assaying using a standard addition technique. The collected receptor fluids were digested by adding $4.7 \mathrm{~mL}$ of $2 \%$ $(v / v) \mathrm{HNO}_{3}(69 \%$ ultra-pure grade for ICP-MS, Choice Analytical, Australia) to $0.3 \mathrm{~mL}$ of each receptor fluid to make up solution volume of $5 \mathrm{~mL}$. To digest the tapes and remaining HSE, $6 \mathrm{~mL}$ of $\mathrm{HNO}_{3}$ (69\% ultra-pure grade for ICP-MS, Choice Analytical, Australia) and $1 \mathrm{~mL}$ of $\mathrm{H}_{2} \mathrm{O}_{2}$ (Westfarmer Chemicals, $30 \% \mathrm{v} / \mathrm{v}$ ) were added to each. To digest the sponges, $3 \mathrm{~mL}$ of $\mathrm{HNO}_{3}$ was added. Afterwards, the samples were heated up in a heater block by increasing the temperature gradually from $35^{\circ} \mathrm{C}$ to $100{ }^{\circ} \mathrm{C}$ until digestion of organic compounds was completed, and bubbling stopped. The collected gelatine samples were, first, mixed with $1 \mathrm{~mL}$ of $\mathrm{HNO}_{3}$ and heated at $60^{\circ} \mathrm{C}$ for $3 \mathrm{~h}$. All acid-digested samples were diluted with ultrapure $\mathrm{MQ}$ water to make the acid content $\leq 2 \%(v / v)$ and aliquoted accordingly. For the calibration curve sets, the aliquots of the acid-digested samples were spiked with a certified ${ }^{67} \mathrm{Zn}$ standard solution (IRMM ${ }^{\circledR}$ Certified Reference Material, SigmaAldrich, Sydney, NSW, Australia) at different concentrations. A calibration set of the skin assay samples was $0,10,20,50,100,200$ and $500 \mathrm{ppb}$; and 0, 1.5, 3, 6, 12, and $16 \mathrm{ppb}$ for the gelatine samples.

\subsection{Solution Nebulisation ICP-MS}

Trace element concentrations of the samples were measured using solution-based ICPMS [Agilent 8900 Triple Quad (QQQ)] with a helium gas collision cell (Agilent Technologies, Tokyo, Japan) at University of Adelaide. An internal standard, yttrium, was mixed online with the samples to compensate for matrix effects. Blanks were interspersed throughout the analysis session, as well as the measurement of a 50-ppb calibration solution to check the instrument stability. The torch depth was $10 \mathrm{~mm}$, octupole RF power was $170 \mathrm{~V}$ and argon carrier gas flow was $1.05 \mathrm{~L} / \mathrm{min}$. The measurement was performed using an 
octupole collision cell, with helium gas flow $5.0 \mathrm{~mL} / \mathrm{min}$ to avoid polyatomic interferences. Five replicates were acquired for each sample. The data was processed using Agilent MassHunter Data AnalysisTM.

\subsection{Cell Culture and MTT Cytotoxicity Assay}

Immortalised human keratinocytes cell line (HaCaT) was cultured in DMEM (highglucose, Sigma-Aldrich) supplemented with 10\% FBS (Sigma-Aldrich) and 1\% PenicillinStreptomycin Solution (P/S, Life Technologies, Carlsbad, CA, USA), then incubated at $37{ }^{\circ} \mathrm{C}$ under a humidified atmosphere of $5 \% \mathrm{CO}_{2} / 95 \%$ air. After 4 passages, cells were detached with trypsin and seeded in a 96-well plate (Corning Costar, Corning, NY, USA) at a density of 50,000 cells per well. HaCaT cells are a commonly used cell line that offer a robust and reproducible model for assessing keratinocyte cytotoxicity by removing inherent donor variability observed when using primary keratinocytes.

To perform a cytotoxicity test, $1 \mathrm{~mL}$ of stock suspension of ${ }^{67} \mathrm{ZnO}-\mathrm{PEG}$ NPs $(1 \mathrm{mg} / \mathrm{mL})$ in DMEM was prepared, following ultrasonication for $30 \mathrm{~min}$, then diluted to concentrations ranging from 10 to $100 \mu \mathrm{g} / \mathrm{mL}$. In addition, solutions of zinc salts, zinc sulphate heptahydrate $\left(\mathrm{ZnSO}_{4} .7 \mathrm{H}_{2} \mathrm{O}\right.$; Sigma-Aldrich, Saint Louis, $\left.\mathrm{MO}, \mathrm{USA}\right)$, and zinc acetate dihydrate $\left(\mathrm{Zn}\left(\mathrm{C}_{2} \mathrm{H}_{3} \mathrm{O}_{2}\right)_{2} .2 \mathrm{H}_{2} \mathrm{O}\right.$; Sigma-Aldrich, Saint Louis, MO, USA) were prepared at concentrations adjusted to the same $\mathrm{Zn}$ molar content as that of $\mathrm{ZnO}$ NPs. Eight wells were tested for each concentration and 8 wells were kept as control untreated cells. The media was removed $24 \mathrm{~h}$ later, cells were washed with PBS and then were exposed to freshly prepared dilutions of ZnO NPs for testing concentrations. After $24 \mathrm{~h}$, cells were washed twice with PBS, and the cell viability was determined by MTT (3-(4,5-Dimethythiazolyl)2,5-diphenyl-2H-tetrazolium bromide) colourimetric assay. Briefly, $100 \mu \mathrm{L}$ of MTT reagent $(0.5 \mathrm{mg} / \mathrm{mL}$ in the phenol red-free cell culture medium; DMEM/F12; \#D6434, SigmaAldrich, Sydney, NSW, Australia) was added to each well, followed by incubation at $37^{\circ} \mathrm{C}$ for $1 \mathrm{~h}$ to allow precipitation of insoluble formazan crystals. Then the supernatant was carefully discarded and $100 \mu \mathrm{L}$ of DMSO (dimethyl sulfoxide) was added to each well and left for $10 \mathrm{~min}$ in dark on a plate shaker at room temperature to allow violet formazan crystals to be dissolved. The absorbance of the MTT product was measured at $550 \mathrm{~nm}$ using a PHERAstar microplate reader (BMG Labtech, Ortenberg, Germany) and the cell viability for each concentration was calculated relative to the untreated cells using the following equation [73]:

$$
\operatorname{Viability~}(\%)=\frac{\langle\text { absorbance of treated cells }\rangle-\langle\text { blank }\rangle}{\langle\text { control }\rangle-\langle\text { blank }\rangle} \times 100 \%,
$$

\langle\rangle denotes mean value.

\subsection{Determination of Labile Zinc Species in Cell-Mediated Culture Media}

$\mathrm{HaCaT}$ cells were cultured as described in Section 3.10 and dosed with blank, low $(5 \mu \mathrm{g} / \mathrm{mL})$, mid $(25 \mu \mathrm{g} / \mathrm{mL})$ and high $(50 \mu \mathrm{g} / \mathrm{mL})$ concentrations of ${ }^{67} \mathrm{ZnO}$ NPs for $24 \mathrm{~h}$. 0.5-mL aliquots of the cell-conditioned media were placed into thick wall polycarbonate tubes and processed by ultra-centrifugation (Beckman-Coulter, Sydney, NSW, Australia) at $100,000 \times g$ for $45 \mathrm{~min}$ at $4{ }^{\circ} \mathrm{C}$. The supernatants were collected and an aliquot of $180 \mu \mathrm{L}$ of each sample was added to a black 96-well plate. $20 \mu \mathrm{L}$ of $2-\mu \mathrm{M}$ ZP1 solution was added to each well, including the blank, and agitated. Fluorescence was read out from each plate, excitation/emission, $490 \mathrm{~nm} / 530 \mathrm{~nm}$, respectively. The concentration of labile zinc, $C_{Z n}$ in each sample was evaluated by using the following equation:

$$
C_{Z n}=k_{d} \frac{F-F_{\min }}{F_{\max }-F}
$$

where $k_{d}$ stands for the dissociation constant reported being $0.7 \mathrm{nM}$ for ZP1 [74]. F is the fluorescence intensity of the samples after addition of 2- $\mu \mathrm{M} Z \mathrm{P} 1$. $F_{\text {min }}$-the fluorescence 
intensity of the blank DMEM cell culture media containing $50 \mu \mathrm{M}$ of TPEN $(\mathrm{N}, \mathrm{N}, \mathrm{N}, \mathrm{N}-$ Tetrakis(2-pyridylmethyl)-ethylenediamine), $F_{\max }$ - the fluorescence intensity of the blank DMEM cell culture media with $5 \mathrm{mM}$ of added $\mathrm{ZnSO}_{4}$.

Alternatively, the ${ }^{67} \mathrm{Zn}$ concentration in the sample supernatants was quantified by solution-based ICP-MS, as previously outlined in Section 3.9.

\subsection{Statistical Analysis}

Statistical analysis of obtained data was performed using GraphPad Prism software (version 9.2.0). One-way ANOVA and Mann-Whitney tests were performed on normally and non-normally distributed data, respectively, to determine significance of the mean difference between the blank and $\mathrm{ZnO}$-treated samples. $p$-values $<0.05$ were deemed statistically significant.

\section{Conclusions}

Whilst there has been concern about the general safety of zinc oxide nanoparticle sunscreens in topical products, work to date has focussed on whether nanoparticles can be found in the viable epidermis after permeation through the SC and via furrows and the follicles, including by lateral diffusion [75]. These zinc oxide nanoparticles, in turn, release zinc ions when the skin $\mathrm{pH}$ is either neutral or acidic and high zinc ion concentrations have been shown to be toxic in isolated keratinocytes [41]. Here, the use of ${ }^{67} \mathrm{Zn}$ tagged nanoparticles enabled analysis of exogenous zinc ion concentrations in viable skin after topical application of zinc oxide nanoparticles.

The percutaneously absorbed ${ }^{67} \mathrm{Zn}$ was quantified by inductively coupled plasmamass spectrometry (ICP-MS) and laser-ablation ICP-MS to its elevated concentration in the VE as $1.0 \pm 0.3 \mu \mathrm{g} / \mathrm{mL}(2.1 \pm 0.5 \mu \mathrm{g}$ per g of dry skin), much lower than our estimated endogenous total zinc ion concentration in the viable epidermis of $4.3 \pm 0.7 \mu \mathrm{g} / \mathrm{mL}$ (13 $\pm 2 \mu \mathrm{g} / \mathrm{g}$ of dry skin). Both are, in turn, much lower than the potentially cytotoxic labile ${ }^{67} \mathrm{Zn}$ concentrations of $21-31 \mu \mathrm{g} / \mathrm{mL}$ in serum-supplemented culture media causing keratinocyte HaCaT cytotoxicity. Therefore, the zinc concentration detected in VE with and without $\mathrm{ZnO}$ NP application was found to be significantly lower than the HaCaT cytotoxicity threshold. As such, our study validates the estimates recently made by Yamada et al. [18]. Furthermore, our work supports the recent FDA proposal for sunscreen marketing that only two of the 16 currently marketed sunscreens, zinc oxide and titanium dioxide, can generally be regarded as safe and effective [76]. This paper provides strong evidence that the NP form of $\mathrm{ZnO}$ sunscreens is safe after topical application to intact human skin.

Supplementary Materials: The following are available online at https:/ / www.mdpi.com/article/10 $.3390 /$ ijms222212372/s1.

Author Contributions: Conceptualization, A.V.Z. and M.S.R.; methodology, Z.K., A.M.H., Y.-J.L., L.L.; A.D. and M.A.P.; software, Z.K.; validation, Z.K., A.M.H. and Y.-J.L.; formal analysis, Z.K.; investigation, Z.K. and A.M.H.; resources, Z.K. and A.M.H.; data curation, Z.K.; writing-original draft preparation, Z.K.; writing-review and editing, Z.K., A.M.H., A.V.Z. and M.S.R.; visualization, Z.K.; supervision, A.V.Z. and M.S.R.; project administration, Z.K. and A.V.Z.; funding acquisition, A.V.Z. and M.S.R. All authors have read and agreed to the published version of the manuscript.

Funding: This research received no external funding.

Data Availability Statement: The data presented in this study are available from the corresponding author on reasonable request. 
Acknowledgments: We would like to acknowledge an Australian Government Research Training Program (RTP) Scholarship and Russian Foundation for Basic Research (grant No 20-04-00182) for supporting instrumental and material aspects of this project. AMH, MSR would like to acknowledge the NHMRC (1107356), ARC and Quality Medication Care Pty Ltd. for the financial support of the project related to the cell experiments. We also acknowledge Anna Guller for helping with the cytotoxicity test. We are grateful to Diona Damian and Vanisri Raviraj (Sydney University) for sharing $\mathrm{HaCaT}$ cells.

Conflicts of Interest: The authors declare no conflict of interest.

\section{References}

1. Raj, S.; Jose, S.; Sumod, U.; Sabitha, M. Nanotechnology in cosmetics: Opportunities and challenges. J. Pharm. Bioallied Sci. 2012, 4, 186. [CrossRef] [PubMed]

2. Chaudhri, N.; Soni, G.C.; Prajapati, S. Nanotechnology: An advance tool for nano-cosmetics preparation. Int. J. Pharma Res. Rev. 2015, 4, 28-40.

3. Ahmad, U.; Ahmad, Z.; Khan, A.A.; Akhtar, J.; Singh, S.P.; Ahmad, F.J. Strategies in development and delivery of nanotechnology based cosmetic products. Drug Res. 2018, 68, 545-552. [CrossRef]

4. $\quad$ Roberts, M.S.; Mohammed, Y.H.; Pastore, M.; Namjoshi, S.; Yousef, S.; Alinaghi, A.; Haridass, I.N.; Abd, E.; Leite-Silva, V.R.; Benson, H.A.E.; et al. Topical and cutaneous delivery using nanosystems. J. Control. Release 2017, 247, 86-105. [CrossRef]

5. Prow, T.W.; Grice, J.E.; Lin, L.L.; Faye, R.; Butler, M.; Becker, W.; Wurm, E.M.; Yoong, C.; Robertson, T.A.; Soyer, H.P.; et al. Nanoparticles and microparticles for skin drug delivery. Adv. Drug Deliv. Rev. 2011, 63, 470-491. [CrossRef]

6. Zhang, L.; Gu, F.; Chan, J.; Wang, A.; Langer, R.; Farokhzad, O. Nanoparticles in medicine: Therapeutic applications and developments. Clin. Pharmacol. Ther. 2008, 83, 761-769. [CrossRef]

7. McDonald, T.O.; Siccardi, M.; Moss, D.; Liptrott, N.; Giardiello, M.; Rannard, S.; Owen, A. The application of nanotechnology to drug delivery in medicine. Chapter 2015, 2, 173-223.

8. Kargozar, S.; Mozafari, M.M. Nanotechnology and Nanomedicine: Start small, think big. Mater. Today Proc. 2018, 5, 15492-15500. [CrossRef]

9. Wiesner, M.R.; Lowry, G.V.; Alvarez, P.; Dionysiou, D.; Biswas, P. Assessing the Risks of Manufactured Nanomaterials; ACS Publications: Washington, DC, USA, 2006.

10. Colvin, V.L. The potential environmental impact of engineered nanomaterials. Nat. Biotechnol. 2003, 21, 1166. [CrossRef]

11. Hull, M.; Bowman, D. Nanotechnology Environmental Health and Safety: Risks, Regulation, and Management; William Andrew: Norwich, New York, NY, USA, 2018.

12. Nel, A.; Xia, T.; Mädler, L.; Li, N. Toxic potential of materials at the nanolevel. Science 2006, 311, 622-627. [CrossRef]

13. Karahalil, B. Challenges, Recommendations, and Strategies for Nanotoxicology Evaluation and Its Management. In Nanotoxicology; CRC Press: Boca Raton, USA, 2018; pp. 649-655.

14. Piccinno, F.; Gottschalk, F.; Seeger, S.; Nowack, B. Industrial production quantities and uses of ten engineered nanomaterials in Europe and the world. J. Nanopart. Res. 2012, 14, 1109. [CrossRef]

15. Nohynek, G.J.; Lademann, J.; Ribaud, C.; Roberts, M.S. Grey goo on the skin? Nanotechnology, cosmetic and sunscreen safety. Crit. Rev. Toxicol. 2007, 37, 251-277. [CrossRef]

16. Smijs, T.G.; Pavel, S. Titanium dioxide and zinc oxide nanoparticles in sunscreens: Focus on their safety and effectiveness. Nanotechnol. Sci. Appl. 2011, 4, 95. [CrossRef]

17. Berube, D.M. Rhetorical gamesmanship in the nano debates over sunscreens and nanoparticles. J. Nanopart. Res. 2008, 10, 23-37. [CrossRef]

18. Yamada, M.; Mohammed, Y.; Prow, T.W. Advances and controversies in studying sunscreen delivery and toxicity. Adv. Drug Deliv. Rev. 2020, 135, 72-86. [CrossRef] [PubMed]

19. Sharma, V.; Singh, S.K.; Anderson, D.; Tobin, D.J.; Dhawan, A. Zinc oxide nanoparticle induced genotoxicity in primary human epidermal keratinocytes. J. Nanosci. Nanotechnol. 2011, 11, 3782-3788. [CrossRef]

20. Lee, S.H.; Pie, J.-E.; Kim, Y.-R.; Lee, H.R.; Son, S.W.; Kim, M.-K. Effects of zinc oxide nanoparticles on gene expression profile in human keratinocytes. Mol. Cell. Toxicol. 2012, 8, 113-118. [CrossRef]

21. Sharma, V.; Shukla, R.K.; Saxena, N.; Parmar, D.; Das, M.; Dhawan, A. DNA damaging potential of zinc oxide nanoparticles in human epidermal cells. Toxicol. Lett. 2009, 185, 211-218. [CrossRef] [PubMed]

22. Wu, Z.; Yang, H.; Archana, G.; Rakshit, M.; Ng, K.W.; Tay, C.Y.J.N. Human keratinocytes adapt to ZnO nanoparticles induced toxicity via complex paracrine crosstalk and Nrf2-proteasomal signal transduction. Nanotoxicology 2018, 12, 1215-1229. [CrossRef]

23. Shuilleabhain, S.N.; Mothersill, C.; Sheehan, D.; O’Brien, N.; O’Halloran, J.; Van Pelt, F.; Davoren, M. In vitro cytotoxicity testing of three zinc metal salts using established fish cell lines. Toxicol. Vitr. 2004, 18, 365-376. [CrossRef]

24. Song, W.; Zhang, J.; Guo, J.; Zhang, J.; Ding, F.; Li, L.; Sun, Z. Role of the dissolved zinc ion and reactive oxygen species in cytotoxicity of ZnO nanoparticles. Toxicol. Lett. 2010, 199, 389-397. [CrossRef]

25. Momose, A.; Shiraiwa, Y.; Narita, S.; Kusumi, T.; Goto, S.; Sera, K.J.N. Total Calcium and Albumin Are Decreased in the Deeper Epidermis of Patients with Chronic Kidney Disease-Associated Pruritus. Nephron 2017, 136, 103-110. [CrossRef] 
26. Michaelsson, G.; Ljunghall, K.; Danielson, B.J. Zinc in epidermis and dermis in healthy subjects. Acta Derm. Venereol. 1980, 60, 295-299. [PubMed]

27. Gamer, A.; Leibold, E.v.; Van Ravenzwaay, B. The in vitro absorption of microfine zinc oxide and titanium dioxide through porcine skin. Toxicol. Vitr. 2006, 20, 301-307. [CrossRef] [PubMed]

28. Cross, S.E.; Innes, B.; Roberts, M.S.; Tsuzuki, T.; Robertson, T.A.; McCormick, P. Human skin penetration of sunscreen nanoparticles: In-vitro assessment of a novel micronized zinc oxide formulation. Ski. Pharmacol. Physiol. 2007, 20, 148-154. [CrossRef]

29. Zvyagin, A.V.; Zhao, X.; Gierden, A.; Sanchez, W.; Ross, J.A.; Roberts, M.S. Imaging of zinc oxide nanoparticle penetration in human skin in vitro and in vivo. J. Biomed. Opt. 2008, 13, 064031-064039. [CrossRef] [PubMed]

30. Roberts, M.S.; Roberts, M.J.; Robertson, T.A.; Sanchez, W.; Thörling, C.; Zou, Y.; Zhao, X.; Becker, W.; Zvyagin, A.V. In vitro and in vivo imaging of xenobiotic transport in human skin and in the rat liver. J. Biophotonics 2008, 1, 478-493. [CrossRef]

31. Holmes, A.M.; Song, Z.; Moghimi, H.R.; Roberts, M.S. Relative penetration of zinc oxide and zinc ions into human skin after application of different zinc oxide formulations. ACS Nano 2016, 10, 1810-1819. [CrossRef]

32. Watkinson, A.C.; Bunge, A.L.; Hadgraft, J.; Lane, M.E. Nanoparticles do not penetrate human skin-A theoretical perspective. Pharm. Res. 2013, 30, 1943-1946. [CrossRef]

33. Leite-Silva, V.R.; Sanchez, W.Y.; Studier, H.; Liu, D.C.; Mohammed, Y.H.; Holmes, A.M.; Ryan, E.M.; Haridass, I.N.; Chandrasekaran, N.C.; Becker, W.; et al. Human skin penetration and local effects of topical nano zinc oxide after occlusion and barrier impairment. Eur. J. Pharm. Biopharm. 2016, 104, 140-147. [CrossRef] [PubMed]

34. Filipe, P.; Silva, J.; Silva, R.; De Castro, J.C.; Gomes, M.M.; Alves, L.; Santus, R.; Pinheiro, T. Stratum corneum is an effective barrier to $\mathrm{TiO}_{2}$ and $\mathrm{ZnO}$ nanoparticle percutaneous absorption. Ski. Pharmacol. Physiol. 2009, 22, 266-275. [CrossRef]

35. Leite-Silva, V.R.; Liu, D.C.; Sanchez, W.Y.; Studier, H.; Mohammed, Y.H.; Holmes, A.; Becker, W.; Grice, J.E.; Benson, H.A.; Roberts, M.S. Effect of flexing and massage on in vivo human skin penetration and toxicity of zinc oxide nanoparticles. Nanomedicine 2016, 11, 1193-1205. [CrossRef]

36. GoodsAdmnistration, Therapeutic. Literature review on the safety of titanium dioxide and zinc oxide on nanoparticles in sunscreens. Dep. Health Ageing 2013.

37. Ohman, H.; Vahlquist, A. In vivo studies concerning a $\mathrm{pH}$ gradient in human stratum corneum and upper epidermis. Acta Derm. Venereol. Stockh. 1994, 74, 375-379.

38. Ågren, M.S. Percutaneous absorption of zinc from zinc oxide applied topically to intact skin in man. Dermatology 1990, 180, 36-39. [CrossRef]

39. Pirot, F.; Millet, J.; Kalia, Y.; Humbert, P. In vitro study of percutaneous absorption, cutaneous bioavailability and bioequivalence of zinc and copper from five topical formulations. Ski. Pharmacol. Physiol. 1996, 9, 259-269. [CrossRef]

40. Holmes, A.M.; Kempson, I.; Turnbull, T.; Paterson, D.; Roberts, M.S. Penetration of zinc into human skin after topical application of nano zinc oxide used in commercial sunscreen formulations. ACS Appl. Bio Mater. 2020, 3, 3640-3647. [CrossRef]

41. Holmes, A.M.; Mackenzie, L.; Roberts, M.S. Disposition and measured toxicity of zinc oxide nanoparticles and zinc ions against keratinocytes in cell culture and viable human epidermis. Nanotoxicology 2020, 14, 263-274. [CrossRef] [PubMed]

42. Mohammed, Y.H.; Holmes, A.; Haridass, I.N.; Sanchez, W.Y.; Studier, H.; Grice, J.E.; Benson, H.A.; Roberts, M.S. Support for the safe use of zinc oxide nanoparticle sunscreens: Lack of skin penetration or cellular toxicity after repeated application in volunteers. J. Investig. Dermatol. 2019, 139, 308-315. [CrossRef]

43. Mohammed, Y.H.; Haridass, I.N.; Grice, J.E.; Benson, H.A.; Roberts, M.S. Bathing Does Not Facilitate Human Skin Penetration or Adverse Cellular Effects of Nanoparticulate Zinc Oxide Sunscreens after Topical Application. J. Investig. Dermatol. 2020, 140, 1656-1659. [CrossRef] [PubMed]

44. Mohammed, Y.H.; Barkauskas, D.S.; Holmes, A.; Grice, J.; Roberts, M.S. Noninvasive in vivo human multiphoton microscopy: A key method in proving nanoparticulate zinc oxide sunscreen safety. J. Biomed. Opt. 2020, 25, 014509. [CrossRef] [PubMed]

45. Cotton, A.F.; Wilkinson, G.; Bochmann, M.; Murillo, C.A. Advanced Inorganic Chemistry; Wiley: New York, NY, USA, 1999.

46. Gulson, B.; McCall, M.; Korsch, M.; Gomez, L.; Casey, P.; Oytam, Y.; Taylor, A.; McCulloch, M.; Trotter, J.; Kinsley, L. Small amounts of zinc from zinc oxide particles in sunscreens applied outdoors are absorbed through human skin. Toxicol. Sci. 2010, 118, 140-149. [CrossRef]

47. Gulson, B.; Wong, H.; Korsch, M.; Gomez, L.; Casey, P.; McCall, M.; McCulloch, M.; Trotter, J.; Stauber, J.; Greenoak, G. Comparison of dermal absorption of zinc from different sunscreen formulations and differing UV exposure based on stable isotope tracing. Sci. Total Environ. 2012, 420, 313-318. [CrossRef] [PubMed]

48. Gulson, B.; Wong, H. Stable isotopic tracing—a way forward for nanotechnology. Environ. Health Perspect. 2006, 114, 1486. [CrossRef] [PubMed]

49. Darvin, M.; König, K.; Kellner-Hoefer, M.; Breunig, H.; Werncke, W.; Meinke, M.; Patzelt, A.; Sterry, W.; Lademann, J. Safety assessment by multiphoton fluorescence/second harmonic generation/hyper-Rayleigh scattering tomography of ZnO nanoparticles used in cosmetic products. Ski. Pharmacol. Physiol. 2012, 25, 219-226. [CrossRef] [PubMed]

50. Joulaud, C.; Mugnier, Y.; Djanta, G.; Dubled, M.; Marty, J.-C.; Galez, C.; Wolf, J.-P.; Bonacina, L.; Le Dantec, R. Characterization of the nonlinear optical properties of nanocrystals by Hyper Rayleigh Scattering. J. Nanobiotechnol. 2013, 11, S8. [CrossRef] [PubMed]

51. Keller, A.A.; Wang, H.; Zhou, D.; Lenihan, H.S.; Cherr, G.; Cardinale, B.J.; Miller, R.; Ji, Z. Stability and aggregation of metal oxide nanoparticles in natural aqueous matrices. Environ. Sci. Technol. 2010, 44, 1962-1967. [CrossRef] 
52. Tso, C.-P.; Zhung, C.-M.; Shih, Y.-H.; Tseng, Y.-M.; Wu, S.-C.; Doong, R.-A. Stability of metal oxide nanoparticles in aqueous solutions. Water Sci. Technol. 2010, 61, 127-133. [CrossRef]

53. Reed, R.B.; Ladner, D.A.; Higgins, C.P.; Westerhoff, P.; Ranville, J.F. Solubility of nano-zinc oxide in environmentally and biologically important matrices. Environ. Toxicol. Chem. 2012, 31, 93-99. [CrossRef]

54. Liu, Z.; Wang, C.; Hou, J.; Wang, P.; Miao, L.; Lv, B.; Yang, Y.; You, G.; Xu, Y.; Zhang, M.J.E.S.; et al. Aggregation, sedimentation, and dissolution of $\mathrm{CuO}$ and $\mathrm{ZnO}$ nanoparticles in five waters. Environ. Sci. Pollut. Res. 2018, 25, 31240-31249. [CrossRef]

55. Al-Ebraheem, A.; Dao, E.; Desouza, E.; Li, C.; Wainman, B.; McNeill, F.; Farquharson, M. Effect of sample preparation techniques on the concentrations and distributions of elements in biological tissues using $\mu$ SRXRF: A comparative study. Physiol. Meas. 2015, 36, N51. [CrossRef]

56. Figueroa, J.A.L.; Vignesh, K.S.; Deepe, G.S.; Caruso, J. Selectivity and specificity of small molecule fluorescent dyes/probes used for the detection of $\mathrm{Zn}^{2+}$ and $\mathrm{Ca}^{2+}$ in cells. Metallomics 2014, 6, 301-315. [CrossRef] [PubMed]

57. Nowakowski, A.B.; Petering, D.H. Reactions of the fluorescent sensor, Zinquin, with the zinc-proteome: Adduct formation and ligand substitution. Inorg. Chem. 2011, 50, 10124-10133. [CrossRef] [PubMed]

58. Karim, M.R. The Role of Proteome in Cellular $\mathrm{Zn}^{2+}$ Trafficking and in the Ability of Fluorescent Zinc Sensors to Image Intracellular $\mathrm{Zn}^{2+}$. Doctoral Dissertation, The University of Wisconsin-Milwaukee, Milwaukee, WI, USA, 2016.

59. Meija, J.; Coplen, T.B.; Berglund, M.; Brand, W.A.; De Bièvre, P.; Gröning, M.; Holden, N.E.; Irrgeher, J.; Loss, R.D.; Walczyk, T. Isotopic compositions of the elements 2013 (IUPAC technical Report). Pure Appl. Chem. 2016, 88, 293-306. [CrossRef]

60. Gorodetsky, R.; Sheskin, J.; Weinreb, A. Iron, copper, and zinc concentrations in normal skin and in various nonmalignant and malignant lesions. Int. J. Dermatol. 1986, 25, 440-445. [CrossRef]

61. Popov, A.; Priezzhev, A.; Lademann, J.; Myllylä, $\mathrm{R}$. $\mathrm{TiO}_{2}$ nanoparticles as an effective UV-B radiation skin-protective compound in sunscreens. J. Phys. D Appl. Phys. 2005, 38, 2564. [CrossRef]

62. Ogawa, H.; Taneda, A.; Kanaoka, Y.; Sekine, T. The histochemical distribution of protein bound sulfhydryl groups in human epidermis by the new staining method. J. Histochem. Cytochem. 1979, 27, 942-946. [CrossRef]

63. Plum, L.M.; Rink, L.; Haase, H. The essential toxin: Impact of zinc on human health. Int. J. Environ. Res. Public Health 2010, 7, 1342-1365. [CrossRef]

64. Bielfeldt, S.; Schoder, V.; Ely, U.; Van Der Pol, A.; De Sterke, J.; Wilhelm, K.P. Assessment of human stratum corneum thickness and its barrier properties by in-vivo confocal Raman spectroscopy. Int. J. Cosmet. Sci. 2009, 31, 479-480. [CrossRef]

65. Pavlica, S.; Gaunitz, F.; Gebhardt, R. Comparative in vitro toxicity of seven zinc-salts towards neuronal PC12 cells. Toxicol. Vitr. 2009, 23, 653-659. [CrossRef] [PubMed]

66. Vinardell, M.P.; Llanas, H.; Marics, L.; Mitjans, M. In Vitro Comparative Skin Irritation Induced by Nano and Non-Nano Zinc Oxide. Nanomaterials 2017, 7, 56. [CrossRef]

67. Jeong, S.H.; Kim, H.J.; Ryu, H.J.; Ryu, W.I.; Park, Y.-H.; Bae, H.C.; Jang, Y.S.; Son, S.W. ZnO nanoparticles induce TNF- $\alpha$ expression via ROS-ERK-Egr-1 pathway in human keratinocytes. J. Dermatol. Sci. 2013, 72, 263-273. [CrossRef] [PubMed]

68. Haase, H.; Hebel, S.; Engelhardt, G.; Rink, L. The biochemical effects of extracellular $\mathrm{Zn}^{2+}$ and other metal ions are severely affected by their speciation in cell culture media. Metallomics 2015, 7, 102-111. [CrossRef] [PubMed]

69. Karlsson, H.L.; Cronholm, P.; Hedberg, Y.; Tornberg, M.; De Battice, L.; Svedhem, S.; Wallinder, I.O. Cell membrane damage and protein interaction induced by copper containing nanoparticles-Importance of the metal release process. Toxicology 2013, 313, 59-69. [CrossRef] [PubMed]

70. Luo, M.; Shen, C.; Feltis, B.N.; Martin, L.L.; Hughes, A.E.; Wright, P.F.; Turney, T.W. Reducing ZnO nanoparticle cytotoxicity by surface modification. Nanoscale 2014, 6, 5791-5798. [CrossRef]

71. Lademann, J.; Jacobi, U.; Surber, C.; Weigmann, H.-J.; Fluhr, J. The tape stripping procedure-evaluation of some critical parameters. Eur. J. Pharm. Biopharm. 2009, 72, 317-323. [CrossRef]

72. Šala, M.; Šelih, V.S.; van Elteren, J.T.J.A. Gelatin gels as multi-element calibration standards in LA-ICP-MS bioimaging: Fabrication of homogeneous standards and microhomogeneity testing. Analyst 2017, 142, 3356-3359. [CrossRef]

73. Liang, L.; Lu, Y.; Zhang, R.; Care, A.; Ortega, T.A.; Deyev, S.M.; Qian, Y.; Zvyaginacd, A.V. Upconversion nanoparticles mediated deep-penetrating photodynamic therapy of KillerRed. Acta Biomater. 2017, 51, 461-470. [CrossRef]

74. Woodroofe, C.C.; Masalha, R.; Barnes, K.R.; Frederickson, C.J.; Lippard, S.J. Membrane-permeable and-impermeable sensors of the Zinpyr family and their application to imaging of hippocampal zinc in vivo. Chem. Biol. 2004, 11, 1659-1666. [CrossRef]

75. Roberts, M.S.; Cheruvu, H.S.; Mangion, S.E.; Alinaghi, A.; Benson, H.A.E.; Mohammed, Y.; Holmes, A.; van der Hoek, J.; Pastore, M.; Grice, J.E. Topical drug delivery: History, percutaneous absorption, and product development. Adv Drug Deliv Rev. 2021, 177, 113929. [CrossRef]

76. Food and Drug Administration. FDA Advances new proposed regulation to make sure that sunscreens are safe and effective. Fed. Regist. 84FR6204 2019, 3019, 2019. 